\title{
Characterizing summertime chemical boundary conditions for airmasses entering the US West Coast
}

\author{
G. G. Pfister ${ }^{1}$, D. D. Parrish ${ }^{2}$, H. Worden ${ }^{1}$, L. K. Emmons ${ }^{1}$, D. P. Edwards ${ }^{1}$, C. Wiedinmyer ${ }^{1}$, G. S. Diskin ${ }^{3}$, G. Huey ${ }^{4}$, \\ S. J. Oltmans ${ }^{2}$, V. Thouret ${ }^{5,6}$, A. Weinheimer ${ }^{1}$, and A. Wisthaler ${ }^{7}$ \\ ${ }^{1}$ Atmospheric Chemistry Division, National Center for Atmospheric Research (NCAR), Boulder, CO, USA \\ ${ }^{2}$ Earth System Research Laboratory, National Oceanic and Atmospheric Administration, Boulder, CO, USA \\ ${ }^{3}$ Chemistry and Dynamics Branch, NASA Langley Research Center, Hampton, VA, USA \\ ${ }^{4}$ School of Earth \& Atmospheric Sciences, Georgia Institute of Technology, Atlanta, GA, USA \\ ${ }^{5}$ Laboratoire d'Aérologie, Centre National de la Recherche Scientifique, Toulouse, France \\ ${ }^{6}$ Université de Toulouse, Toulouse, France \\ ${ }^{7}$ Institute for Ion Physics \& Applied Physics, University of Innsbruck, Innsbruck, Austria
}

Received: 26 October 2010 - Published in Atmos. Chem. Phys. Discuss.: 25 November 2010

Revised: 2 February 2011 - Accepted: 7 February 2011 - Published: 25 February 2011

\begin{abstract}
The objective of this study is to analyze the pollution inflow into California during summertime and how it impacts surface air quality through combined analysis of a suite of observations and global and regional models. The focus is on the transpacific pollution transport investigated by the NASA Arctic Research of the Composition of the Troposphere from Aircraft and Satellites (ARCTAS) mission in June 2008. Additional observations include satellite retrievals of carbon monoxide and ozone by the EOS Aura Tropospheric Emissions Spectrometer (TES), aircraft measurements from the MOZAIC program and ozonesondes. We compare chemical boundary conditions (BC) from the MOZART-4 global model, which are commonly used in regional simulations, with measured concentrations to quantify both the accuracy of the model results and the variability in pollution inflow. Both observations and model reflect a large variability in pollution inflow on temporal and spatial scales, but the global model captures only about half of the observed free tropospheric variability. Model tracer contributions show a large contribution from Asian emissions in the inflow. Recirculation of local US pollution can impact chemical BC, emphasizing the importance of consistency between the global model simulations used for BC and the regional model in terms of emissions, chemistry and transport. Aircraft measurements in the free troposphere over California show similar concentration ranges, variability and
\end{abstract}

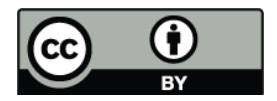

Correspondence to: G. G. Pfister (pfister@ucar.edu) source contributions as free tropospheric air masses over ocean, but caution has to be taken that local pollution aloft is not misinterpreted as inflow. A flight route specifically designed to sample boundary conditions during ARCTASCARB showed a prevalence of plumes transported from Asia and thus may not be fully representative for average inflow conditions. Sensitivity simulations with a regional model with altered BCs show that the temporal variability in the pollution inflow does impact modeled surface concentrations in California. We suggest that time and space varying chemical boundary conditions from global models provide useful input to regional models, but likely still lead to an underestimate of peak surface concentrations and the variability associated with long-range pollution transport.

\section{Introduction}

The importance of lateral boundary conditions (BC) in regional atmospheric transport models or numerical prediction models has been well established in the meteorological community (Brown, 1987; Warner et al., 1997). Much more recently, attention has also been drawn to the consideration of chemical lateral boundary conditions in regional chemical transport models (CTMs) and in air quality simulations, and the importance of the inflow of pollution on local air quality.

Observational studies provide evidence of the long-range pollution transport spanning hemispheric, intercontinental and regional scales. Satellite observations of carbon monoxide (CO) (Heald et al., 2003; Pfister et al., 2010) and ozone

Published by Copernicus Publications on behalf of the European Geosciences Union. 
$\left(\mathrm{O}_{3}\right)$ (Zhang et al., 2008) have confirmed the large distances over which pollutants can be transported. Ziemke et al. (2006) demonstrated the potential of using satellitederived columns of tropospheric ozone $\left(\mathrm{O}_{3}\right)$ in tracking pollution events either regionally or globally. Using observations at a mountaintop in the Azores, Val Martin et al. (2006) showed that North American emissions frequently impacted this remote site. Tracer correlations of $\mathrm{CO}$ and $\mathrm{O}_{3}$ have been used to identify the photochemical $\mathrm{O}_{3}$ enhancement in longrange pollution events (Parrish et al., 1993; Bertschi et al., 2004) and of odd nitrogen $\left(\mathrm{NO}_{\mathrm{y}}\right)$ and $\mathrm{O}_{3}$ to study the export efficiency of anthropogenic emissions (Li et al., 2004; Stohl et al., 2002). However, the quantification of the impact of long-range pollution events on local air quality is challenging.

Recent modeling experiments have attempted to characterize the contribution of long-range pollutant transport. Using global model simulations, Fiore et al. (2009) suggest that for Northern Hemispheric surface $\mathrm{O}_{3}$ the response to foreign emissions is largest in spring and late fall, and that responses to emission reductions of the traditional $\mathrm{O}_{3}$ precursors from a single foreign source region are often $10 \%$ (maximum of $50 \%$ ) of the responses to domestic emission reductions. Jacob et al. (1999) calculated that a tripling of Asian anthropogenic emissions could increase monthly mean surface $\mathrm{O}_{3}$ over the US by $1-6 \mathrm{ppbV}$. And the modeling study by Li et al. (2002) suggested that $20 \%$ of the violations in Europe of the 8-h European Council $\mathrm{O}_{3}$ standard of $55 \mathrm{ppbV}$ would not have occurred without the contribution from pollution transport from North America. The importance of intercontinental pollution transport was recognized in 1994 with the establishment of the Task Force on Hemispheric Transport of Air Pollution (HTAP) by the Executive Body of the UNECE Convention on Long-Range Transboundary Air Pollution.

The methods applied for setting chemical BC in regional air quality models range from the use of a single background value for selected long-lived tracers, through the use of idealized or observed vertical profiles, to using time and space varying output from global CTMs. Tang et al. (2007) studied the sensitivity of regional air quality model simulations for the US to various lateral and top boundary conditions by comparing regional model simulations driven with chemical $\mathrm{BC}$ from three different global models. They found differences in the mean $\mathrm{CO}$ concentrations as large as $40 \mathrm{ppbv}$, and the effects of the $\mathrm{BCs}$ on $\mathrm{CO}$ were important throughout the troposphere, even near the surface. They further conclude that applying BCs without time variation may lead to a significant bias in the predicted variability. Huang et al. (2010) have continued this work with an examination of the same summertime period that we investigate here. They find that characterizing the vertical structure of the BCs is important in summertime air quality simulations for California.

In principle, observations would be preferred for providing chemical $\mathrm{BC}$, but in practice it is not possible to obtain measurements for the necessary species with the spa- tial and temporal resolution required by air quality models. This leads to uncertainties in the chemical BC used (e.g., non-representativeness on temporal scales, spatial interpolation errors), which then affect the results of the regional model simulations. Global models can provide the BC for any needed species for a wide range of spatial and temporal scales, but there is uncertainty in the accuracy of the model results. Our goal in this study is to compare model-generated chemical BCs for the air entering the US West Coast with measured concentrations to quantify both the accuracy of the model results and the variability in pollution inflow, and to examine the sensitivity of the temporal and spatial variability in chemical $\mathrm{BC}$ on surface $\mathrm{O}_{3}$ over California.

In this study we focus on the transpacific pollution transport investigated by the NASA Arctic Research of the Composition of the Troposphere from Aircraft and Satellites (ARCTAS) mission. As part of ARCTAS, the California Air Resources Board (CARB) sponsored one week of flights over California and the eastern North Pacific in June 2008. The objectives were to provide measurements that help to improve state emission inventories for greenhouse gases and aerosols, and to test and improve models of ozone and aerosol pollution (Jacob et al., 2010). A boundary conditions flight was especially designed to capture the pollution inflow into California and to provide observational constraints on chemical BCs to be used in regional air quality models.

Here we examine the characteristics of air entering the US West Coast in regard to magnitude and variability based on ARCTAS-CARB and other measurements and evaluate how well the global Model for Ozone and Related Chemical Tracers (MOZART-4), which is frequently used for chemical BC in regional models, captures the observed characteristics. We limit our analysis to the three longer-lived gases $\mathrm{CO}, \mathrm{O}_{3}$ and peroxyacetyl nitrate (PAN), which likely are transported at sufficient concentrations to affect downwind photochemistry.

The outline of the paper is as follows. In Sect. 2 we introduce the aircraft and satellite observations together with the modeling tools. In Sect. 3 we evaluate the global model for its representativeness of chemical inflow based on comparison to aircraft and satellite measurement, relate observations taken during the ARCTAS-CARB boundary conditions flight to the larger temporal and spatial scales and examine the representativeness of free tropospheric observations over land for pollution inflow. Section 4 presents a sensitivity study to demonstrate the importance of temporal and spatial consideration of chemical BC in a regional air quality simulation. The findings are summarized in Sect. 5 .

\section{Observational data sets and models}

\subsection{In-situ data}

Our analysis includes aircraft measurements of $\mathrm{O}_{3}, \mathrm{CO}$ and PAN onboard the DC-8 as provided in the 1-min merged 
data files (version R8). Ozone was measured with a 4channel chemiluminescence instrument (Weinheimer et al., 1994) with a precision of better than $0.1 \mathrm{ppbV}$ for a $1 \mathrm{~s}$ sampling and an overall uncertainty of about $5 \%$. CO measurements are derived from a diode laser spectrometer (Diskin et al., 2002; Sachse et al., 1987) with the uncertainty given as $2 \%$ or $2 \mathrm{ppbV}$. PAN measurements were conducted using a chemical ionization mass spectrometer (Slusher et al., 2004). The detection limit for PAN measurements is estimated as $7 \mathrm{pptV}$ for a 1-s integration period with an estimated error bar of $15 \%$.

In addition to ARCTAS-CARB aircraft data we make use of data from the MOZAIC (Measurement of OZone, water vapor, carbon monoxide and nitrogen oxides by Airbus In-service airCraft) program (Marenco et al., 1998; http: //mozaic.aero.obs-mip.fr). This program was initiated in 1993 by European scientists, aircraft manufacturers and airlines and provides measurements of reactive gases on several commercial aircraft. CO measurements are made with an improved infrared correlation instrument with a precision of \pm 5 ppbv or $\pm 5 \%$ for a 30 -s averaging time (Nédélec et al., 2003). $\mathrm{O}_{3}$ is measured via dual beam UV absorption technique with an uncertainty of $\pm 2 \mathrm{ppbv}$ or $\pm 2 \%$ (Thouret et al., 1998). MOZAIC collects data along the flight corridors as well as vertical profiles over a large number of airports. In this study we use $\mathrm{CO}$ and $\mathrm{O}_{3}$ measurements taken during ascents and descents over the Los Angeles and Portland airports.

In addition we include ozone profiles measured on sondes launched from Trinidad Head (Oltmans et al., 2008). Trinidad Head is located along the northern coast of California and, because of its relatively remote coastal location (insignificant anthropogenic influences and prevailing maritime airflow), provides an opportunity to observe and monitor both regional and global influences. Ozone is measured using electrochemical sensors. Consistent procedures have been used throughout the 10-year measurement period that began in August 1997 (Johnson et al., 2002). Estimated precision of tropospheric profiles is $\pm 5 \%$. Most observations are done on a weekly schedule with some frequency increased to daily during field campaigns.

\subsection{TES satellite data}

We utilize co-located nadir retrievals of $\mathrm{CO}$ and $\mathrm{O}_{3}$ vertical profiles (Version ID F05_07) from the Tropospheric Emissions Spectrometer (TES), which was launched in July 2004 onboard the NASA EOS Aura satellite in a sun-synchronous orbit (about 1:30 p.m. local mean solar time ascending node). TES is an infrared Fourier transform spectrometer (Beer, 2006) with a ground footprint of each nadir observation of about $5 \mathrm{~km} \times 8 \mathrm{~km}$. We include data from both the nominal operation mode (global survey mode) and from special observations (step-and-stare mode). The sampling for the global survey mode is one observation every $160 \mathrm{~km}$ with 16 orbits per global survey, over a time period of $26 \mathrm{~h}$. The step-and-stare mode spatial sampling is approximately $30 \mathrm{~km}$, but covers only a fraction of an orbit, $\sim 60^{\circ}$ of latitude.

TES profile concentrations, averaging kernels and error covariances are given for 67 pressure levels located mainly in the troposphere and lower stratosphere. TES $\mathrm{CO}$ and $\mathrm{O}_{3}$ profile observations typically have 1 to 2 pieces of information in the troposphere (Rinsland et al., 2006; Jourdain et al., 2007). Both TES CO and ozone profile retrievals have been compared against a variety of aircraft, in-situ, and model studies. The comparison to ozonesonde data (Nassar et al., 2008; Osterman et al., 2008; Worden et al., 2007) and lidar measurements (Richards et al., 2008) shows that TES $\mathrm{O}_{3}$ is biased high by 3-10 ppbV, particularly in the upper troposphere. TES CO profiles are within $15 \%$ of aircraft profiles (Luo et al., 2007; Lopez et al., 2008).

\subsection{Chemistry transport modeling}

The global model used in this study is the Model for Ozone and Related Chemical Tracers MOZART-4, which is described and evaluated in greater detail in Emmons et al. (2010a). It includes a comprehensive chemistry scheme with bulk aerosols for simulating tropospheric ozone and precursors in remote and polluted environments. The simulation includes online calculations of photolysis rates, dry deposition, $\mathrm{H}_{2} \mathrm{O}$, and biogenic emissions (Pfister et al., 2008a). MOZART output is frequently used for boundary conditions in regional chemical transport models (e.g. Tang et al., 2007; Fast et al., 2009; Mena-Carrasco et al., 2009; Lin et al., 2010).

For this study, MOZART-4 was driven by meteorological fields from NCEP (National Centers for Environmental Prediction) -Global Forecasting System (GFS) analyses at a horizontal resolution of $\sim 0.7^{\circ}$ by $0.7^{\circ}$. The vertical resolution of the model consists of 64 hybrid levels between the surface and $2 \mathrm{hPa}(\sim 45 \mathrm{~km})$. Instantaneous model fields were output every three hours. A number of synthetic model tracers are included in the simulations. These include $\mathrm{CO}$ tracers for two different source types, fossil fuel and biofuel sources (FF) and biomass burning sources (BB) for each of the following six regions: contiguous US (US), Alaska and Canada (AkCan), Asia (Asia), Europe and North Africa (EurAf), and Central America (Cam). In addition we track the ozone produced from $\mathrm{NO}_{\mathrm{x}}$ fire emissions within the contiguous US The tagging schemes are described in detail by Lamarque et al. (2005), Pfister et al. (2006) and Hess and Lamarque (2007).

For the regional simulations we apply the Weather Research and Forecasting model with chemistry (WRF-Chem Version 3.1.1) (Grell et al., 2005). The chemistry component of WRF-Chem is fully consistent with the meteorological component (WRF); both use the same transport scheme (mass and scalar preserving), grid (horizontal and vertical), 
and physics scheme. WRF-Chem includes online biogenic emissions and dry deposition and a photolysis scheme that is coupled with hydrometeors as well as aerosols. We run WRF-Chem with the MOZART chemical scheme, i.e. the same gas-phase chemistry as used in the global simulations, which is linked to the Goddard Chemistry Aerosol Radiation and Transport (GOCART) bulk aerosol scheme (Chin et al., 2002). This configuration has recently been released in WRF-Chem V3.2. The regional domain has a spatial resolution of $12 \mathrm{~km} \times 12 \mathrm{~km}$ centered over California with 27 vertical levels between the surface and $50 \mathrm{hPa}$. Meteorological initial and boundary conditions are taken from the NCEP Eta North American Mescoscale (NAM) Analysis with analysis nudging for wind, temperature and humidity applied. Spatially and temporally varying chemical boundary conditions are provided by the MOZART simulation. WRF-Chem is setup to run with the Mellor-Yamada-Janjic boundary layer (Janjic, 2002) scheme and the Noah land surface model (Ek et al., 2003).

Global and regional models are based on the same emission inventories where applicable. Anthropogenic emissions are based upon the US EPA's 2005 National Emissions Inventory (version 3) and over California are replaced by an emission inventory provided by the California Air Resources Board (Jeremy Avis, personal communication). Daily fire emissions have been provided by the Fire INventory from NCAR (FINN Version 1) (Wiedinmyer et al., 2006, 2010). Emissions in MOZART vary daily and in WRF-Chem hourly with the diurnal profile following recommendations by the Western Regional Air Partnership (WRAP; Report to Project No. 178-6, July 2005). Fire emissions in MOZART are released at the lowest model level, while in WRF-Chem the online plume rise module (Freitas et al., 2007) is applied to distribute the fire emissions vertically. Biogenic emissions in both models are calculated online following the Model of Emissions of Gases and Aerosols from Nature (MEGAN) (Guenther et al., 2006). Emissions in the MOZART model for the rest of the globe are based on the ARCTAS emission inventory developed by D. Streets and Qiang Zhang (http:/www.cgrer.uiow.edu/arctas/emissions.html).

\section{Discussion}

\subsection{Chemical BC from ARCTAS-CARB flight over ocean and model results}

One of the scientific objectives of the NASA ARCTASCARB campaign was to investigate the pollution inflow into California from the Pacific, and to characterize the chemical boundary conditions suitable for California regional modeling. For this purpose, one of the science flights (22 June) was designed to include a flight leg off the California coast with extensive vertical sampling and extending over the latitude range from Southern to Northern CA (Fig. 1). The remain-

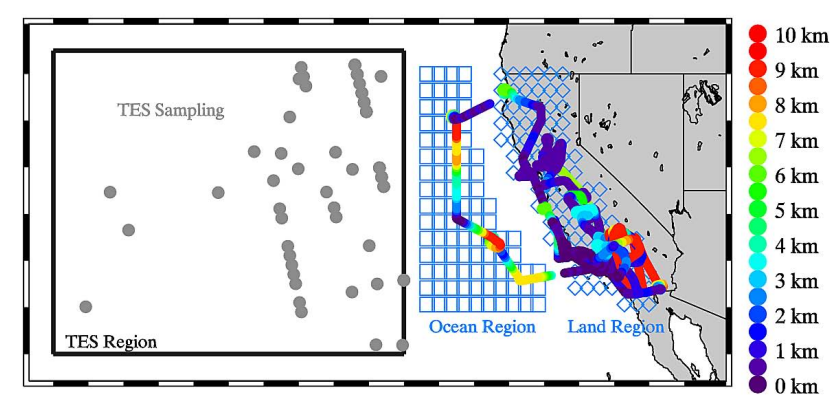

Fig. 1. Locations of observational data sets and modeling regions: Flight tracks of the boundary layer segment on 22 June 2008 and the flights over California are color coded by altitude. The ocean and land region over which additional model statistics (AVGRegion and AVGRegionTime) are performed are indicated by blue squares and blue diamonds, respectively. The TES sampling locations are shown by grey circles and the TES region is outlined by the black box.

der of the flight on 22 June and the other three science flights on 18,20 , and 24 June were performed mostly over land. In this section we perform a statistical analysis of the aircraft measurements over ocean of the longer lived chemical tracers $\left(\mathrm{CO}, \mathrm{O}_{3}, \mathrm{PAN}\right)$, investigate the air mass characteristics in the free troposphere over ocean, and further examine how well the global model represents the observed statistics. Using the model as a reference, we examine the representativeness of the flight sampling in the context of larger regions and longer time periods.

\subsubsection{Measured and modeled concentrations}

As a first step we take a close look at the ocean leg of the flight on 22 June. Figure 1 shows the selected aircraft track and a larger region (Ocean Region), surrounding the aircraft leg, over which additional model statistics are performed. The cutoff points of the flight track are set to mostly exclude plumes from California wildfires sampled towards the coast. The influence of fires is discussed in more detail in Sect. 3.1.3. Figure 2 displays statistics for measured CO, $\mathrm{O}_{3}$ and PAN vertical profiles, which are compared (1) to the model results interpolated to the time and location of the aircraft, (2) to model results corresponding to the flight time (22 June 18UTC) but for the larger spatial region $\left(\mathrm{AVG}^{\text {Region }}\right)$ and (3) to model results over the larger spatial region for the 2-week time period from 15-30 June (AVG $\left.{ }^{\text {RegionTime }}\right)$. The ocean region for $\mathrm{AVG}^{\text {Region }}$ and $\mathrm{AVG}^{\text {RegionTime }}$ is indicated in Fig. 1 by the blue squares and ranges from about 32$43 \mathrm{~N}$ and $120-129 \mathrm{~W}$. Comparing the flight data to a larger model sample allows for temporal or spatial mismatches in the model results. It further allows examination of the overall variability of pollution inflow and puts the flight sampling into a larger regional and temporal perspective. 

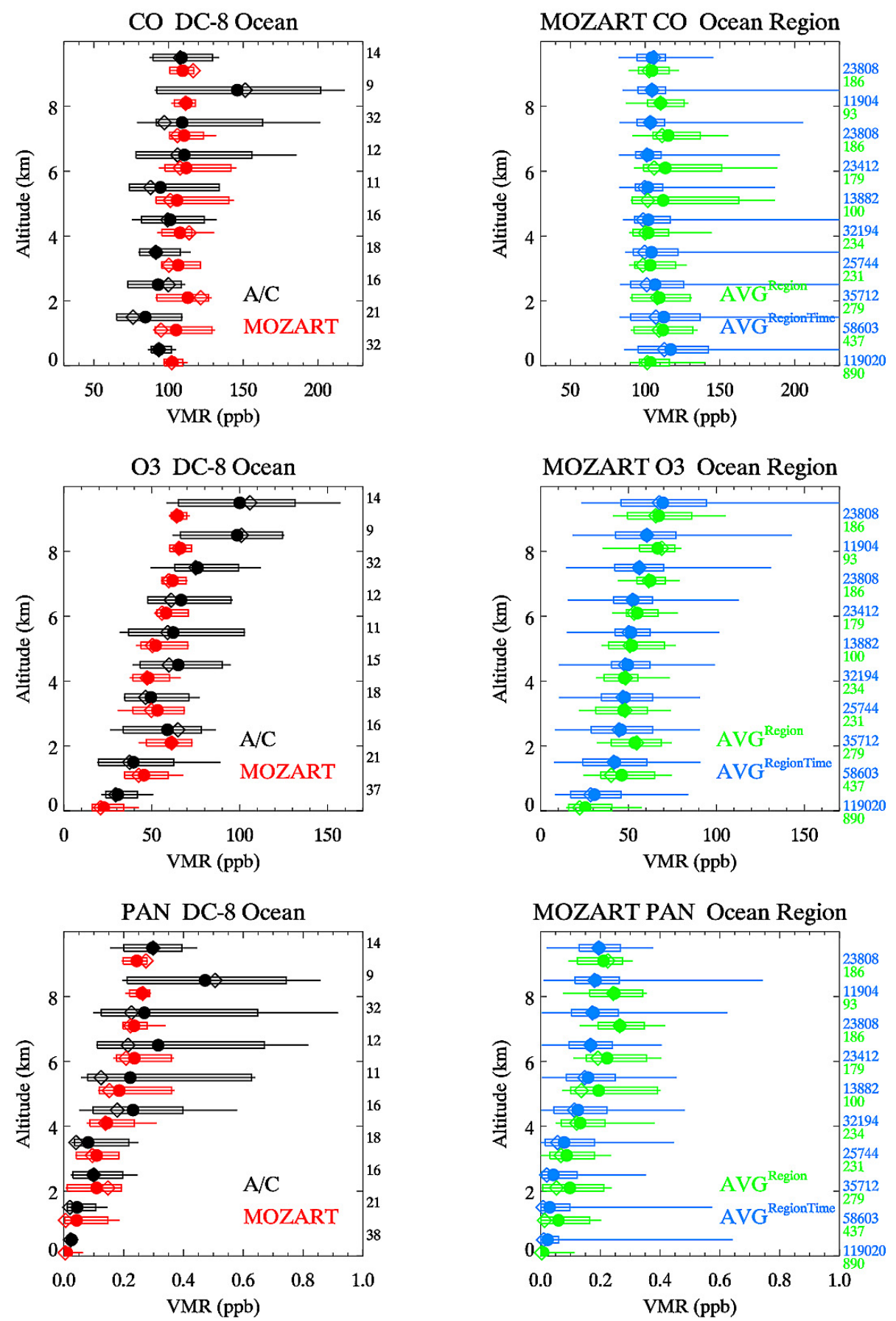

Fig. 2. Observed (black) and modeled (red) statistics for $\mathrm{CO}, \mathrm{O}_{3}$ and PAN vertical profiles along the DC-8 flight track (left-hand side) and for larger temporal and spatial averages (right-hand side; AVGRegion in green and AVGRegionTime in blue; see text and Fig. 1 for more explanation). Shown are mean (filled symbol), median (open symbols), 10th and 90th percentiles (bars) and extremes (lines). The number of data points per $1-\mathrm{km}$ wide altitude bin is shown next to the graphs.

Overall, the model results interpolated to the flight track reproduce the magnitudes and mean profile shapes of measured $\mathrm{CO}, \mathrm{O}_{3}$, and PAN concentrations, but show less variability with smaller extreme values, and overall lower concentrations above $8 \mathrm{~km}$. Both observation and model show lowest $\mathrm{O}_{3}$ and PAN concentrations at the lowest altitudes as expected from surface deposition and thermal decomposition, respectively. The aircraft observations show enhanced values of $\mathrm{CO}, \mathrm{O}_{3}$ and PAN at the higher altitudes $(\sim 7-9 \mathrm{~km})$ indicating the sampling of more concentrated 

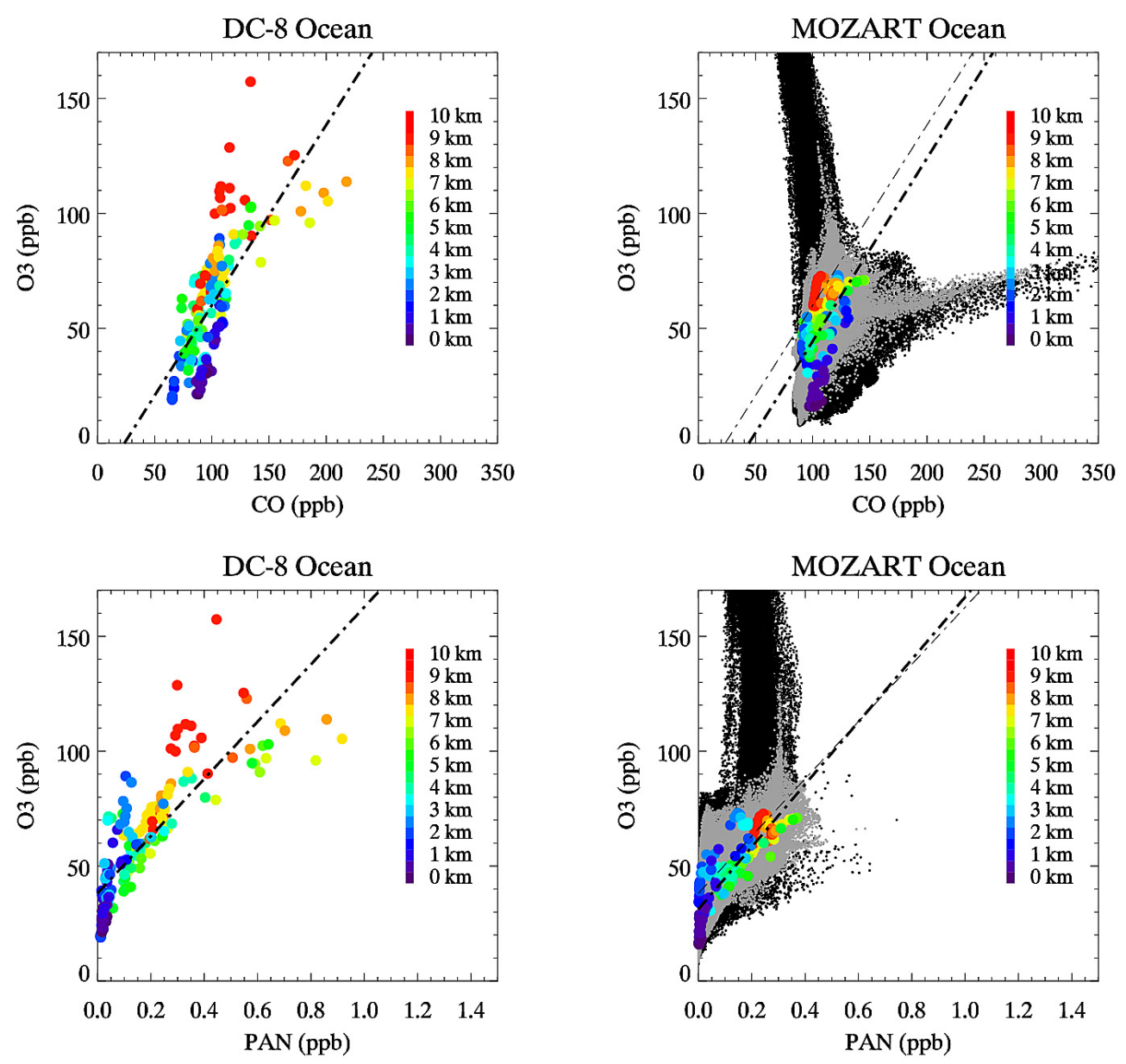

Fig. 3. Observed and modeled $\mathrm{O}_{3}-\mathrm{CO}$ and $\mathrm{O}_{3}$ - PAN relationships for the aircraft path and respective larger regions. Aircraft data are color-coded by altitude as shown in legend. Larger region data (AVGRegionTime) are in black and gray with lighter shades indicating free tropospheric data (altitudes between $2-8 \mathrm{~km}$ ). For illustration purposes, a 2-sided linear regression line to the flight track data is added to the graphs. The thin line in the MOZART plots (right-hand side) is a repeat of the fit to the aircraft observations.

plumes than captured in the model results along the flight track. Back trajectories for these flight segments (provided by H. Fuelberg; http://fuelberg.met.fsu.edu/research/arctas/ traj/traj.html) indicate that these plumes are related to longrange transport of pollution from Asia. At the highest altitude level, low observed $\mathrm{CO}$ and $\mathrm{PAN}$ and high $\mathrm{O}_{3}$ indicates stratospheric influence. While the model simulates the average PAN and $\mathrm{CO}$ concentrations at the highest altitude level well, it significantly underestimates $\mathrm{O}_{3}$ suggesting a low bias in modeled stratospheric $\mathrm{O}_{3}$.

The spatial average (AVG ${ }^{\text {Region }}$, green symbols in Fig. 2) shows enhanced concentrations and variability compared to the modeled flight track concentrations, especially in the middle troposphere around $4-7 \mathrm{~km}$. This indicates that the model does capture concentrated pollution plumes, but that they are placed at lower altitudes compared to the measurements. Despite the larger sample size, the $\mathrm{AVG}^{\text {Region }}$ statistics do not reach the maximum range of the observed concen- trations, pointing to a likely underestimate of the absolute concentrations of pollution plumes in the model. Extremes for $\mathrm{AVG}^{\text {RegionTime }}$ generally are higher than any observed, especially for $\mathrm{CO}$ and $\mathrm{O}_{3}$, although the model does not reproduce the highest PAN concentrations observed above $4 \mathrm{~km}$. The high concentrations are infrequent in the model, and the extreme values in $\mathrm{AVG}^{\text {RegionTime }}$, especially at the lower altitudes, are, generally related to transport of fresh fire plumes from California as will be discussed in more detail later. The upper range spanned by the percentiles is clearly less for all model results compared to the observations, which implies that either the model significantly underestimates the frequency and magnitude of plumes and/or the ARCTASCARB boundary conditions flight sampled above average plume activity. 

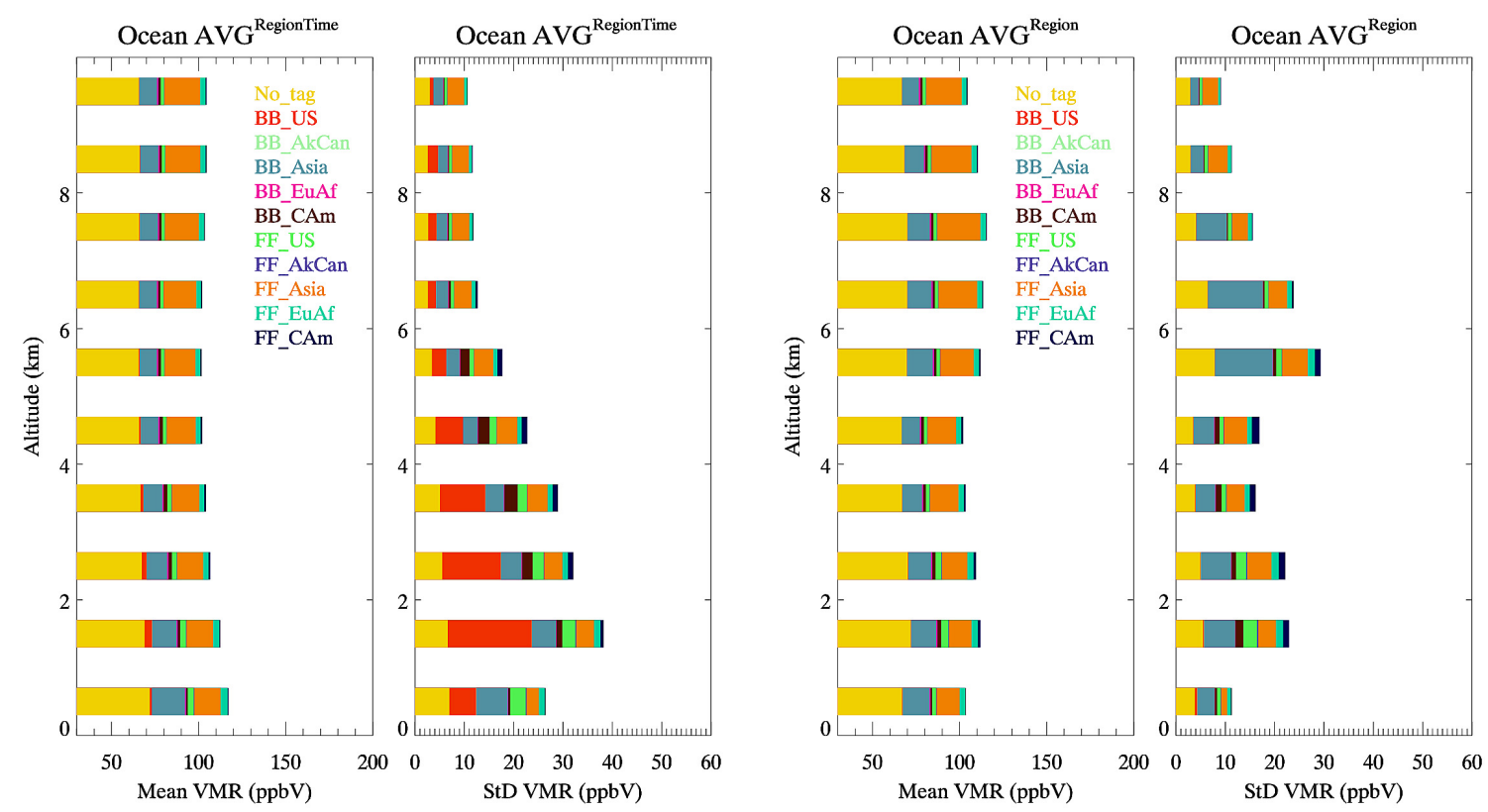

Fig. 4. Modeled CO Tracer concentrations (Mean and STD (ppbV)) for different CO Source types and temporal averages. Results for AVGRegionTime (left-hand side) and AVGRegion (right-hand side). (BB=Biomass burning; FF=Fossil Fuel). The contributions in (\%) per $1 \mathrm{~km}$ high altitude bin and tracer type are given as numbers above each bar. See Table 1 for a summary of 2-8 km contributions.

\subsubsection{Measured and modeled species relationships}

While direct quantitative comparisons of individual species are crucial for evaluating the capability of a model to reproduce observed concentrations with regard to the magnitude, vertical distribution and variability, it is also essential to evaluate the model fields in terms of accurately representing relationships between different species. For this purpose we examine the data as scatter plots showing the relationships for $\mathrm{CO}-\mathrm{O}_{3}$ and $\mathrm{PAN}_{-} \mathrm{O}_{3}$ (Fig. 3). The observed and modeled flight track concentrations as well as $\mathrm{AVG}^{\text {RegionTime }}$ results (gray and black points) are shown. The model reproduces observed correlations well for the low and moderate concentration ranges where the bulk of the data is located. This is also demonstrated by the comparison of the two-sided linear fits calculated for the observed and modeled flight points. However, the model fails to reproduce relationships of high $\mathrm{O}_{3}, \mathrm{CO}$ and PAN concentrations at altitudes of about $7-10 \mathrm{~km}$, which, as mentioned earlier, is likely linked to pollution from Asia.. The strong $\mathrm{O}_{3}$ enhancements may be related to ozone production during the long-range transport of pollution plumes with different degrees of mixing with stratospheric air. Steep $\mathrm{O}_{3}$ gradients at high altitudes are generally an indication of stratospheric influence.

Not only the model results interpolated to the flight track, but also the larger model sample $\mathrm{AVG}^{\text {RegionTime }}$ are missing the representation of these observed correlations of substantial $\mathrm{CO}$ and PAN enhancements with varying $\mathrm{O}_{3}$ enhancements. A number of factors might be responsible for this missing representation: uncertainty in the magnitude and emission ratios in the Asian inventory, missing representation of direct injection of fire emissions into the free troposphere, model transport errors, insufficient mixing with stratospheric air, and/or too little $\mathrm{O}_{3}$ produced from lightning generated $\mathrm{NO}_{\mathrm{x}}$. Also the coarse spatial resolution of the model likely has an impact. Even though the grid resolution of 0.7 degrees $\times 0.7$ degrees used here is fairly high for a global model, it still causes the model to overpredict chemical and physical dilution. Rastigejev et al. (2010) found that Eulerian chemical transport models (CTMs) have difficulty reproducing the layered structures of synoptic-scale pollution plumes in the free troposphere due to numerical plume dissipation and conclude that proper simulation of such a plume would require an impractical increase in grid resolution.

Aside from the bulk of the model results with low to moderate $\mathrm{CO}$ and $\mathrm{O}_{3}, \mathrm{AVG}^{\text {RegionTime }}$ shows two pronounced branches. The one with low $\mathrm{CO}$ and PAN values and steep increases in $\mathrm{O}_{3}$ indicates stratospheric air with no or minor mixing with tropospheric pollution and is generally confined to the high altitudes $(>8 \mathrm{~km})$. A second branch with strong increases in $\mathrm{CO}$ and moderate increases in $\mathrm{O}_{3}$ is indicative of relatively fresh fossil fuel, biofuel and fire emissions. Both of these branches are missing in the flight data indicating that the flight sampling included neither pure stratospheric air nor fresh pollution plumes. 
Table 1. Average CO Source Contributions for different CO tracers for AVGRegionTime Ocean data selections (entire data set; entire data set but with fire influenced data omitted; entire data set but selected for wind directions towards the continent) and the TES region for the $2-8 \mathrm{~km}$ altitude range. The latter is discussed in Sect. 3.3.1. Units are ppbV CO.

\begin{tabular}{lrrrr}
\hline & Ocean ALL & Ocean noFire & $\begin{array}{r}\text { Ocean ALL } \\
\text { WindDir 200-340 deg }\end{array}$ & $\begin{array}{r}\text { TES Region } \\
(130-150 \mathrm{~W}, 30-43 \mathrm{~N})\end{array}$ \\
\hline NoTag & $66.2 \pm 4.3$ & $66.0 \pm 4.1$ & $66.5 \pm 4.0$ & $66.8 \pm 5.1$ \\
BB_US & $1.3 \pm 7.0$ & $0.3 \pm 0.5$ & $0.4 \pm 1.9$ & $0.4 \pm 2.6$ \\
BB_AKCan & $0.0 \pm 0.0$ & $0.0 \pm 0.0$ & $0.0 \pm 0.0$ & $0.0 \pm 0.0$ \\
BB_Asia & $10.6 \pm 3.3$ & $10.5 \pm 3.3$ & $10.6 \pm 3.5$ & $12.7 \pm 5.0$ \\
BB_EuAf & $0.8 \pm 0.1$ & $0.8 \pm 0.1$ & $0.9 \pm 0.1$ & $0.8 \pm 0.1$ \\
BB_Cam & $1.7 \pm 2.0$ & $1.7 \pm 2.0$ & $1.8 \pm 2.0$ & $1.2 \pm 0.4$ \\
FF_US & $2.2 \pm 1.6$ & $2.0 \pm 1.0$ & $2.0 \pm 1.1$ & $2.3 \pm 1.2$ \\
FF_AKCan & $0.2 \pm 0.1$ & $0.2 \pm 0.1$ & $0.2 \pm 0.1$ & $0.2 \pm 0.1$ \\
FF_Asia & $17.0 \pm 4.2$ & $17.0 \pm 4.3$ & $16.8 \pm 4.4$ & $18.4 \pm 4.8$ \\
FF_EuAf & $2.9 \pm 0.9$ & $2.9 \pm 0.9$ & $2.9 \pm 0.9$ & $3.3 \pm 1.2$ \\
FF_Cam & $0.9 \pm 1.0$ & $0.9 \pm 1.0$ & $1.0 \pm 1.1$ & $0.6 \pm 0.2$ \\
\hline
\end{tabular}

\subsubsection{Model tagged species}

To understand the origin of air masses carrying pollution plumes and to explore further the representativeness of the 22 June flight, we examine the source contributions using the model $\mathrm{CO}$ tracers for the 2-week period $\left(\mathrm{AVG}^{\text {RegionTime }}\right)$ and for the day of the flight ( $A V G^{\text {Region }}$ ) over the selected Ocean region. While the model shows an underrepresentation of high CO events, the comparison with the flight data in Fig. 2 as well as model evaluation results from previous studies (Pfister et al., 2008b, 2009; Emmons et al., 2010a, b) give confidence in the overall model performance for $\mathrm{CO}$ emissions, transport and distribution. Source contributions are analyzed by sampling model $\mathrm{CO}$ tracers for $\mathrm{AVG}^{\text {RegionTime }}$ and $\mathrm{AVG}^{\text {Region }}$ selections (Fig. 4). The term "No tag" refers to the difference between the total $\mathrm{CO}$ and the sum of the individual $\mathrm{CO}$ tracers and is mostly due to $\mathrm{CO}$ produced from the photochemical oxidation of methane and other organic species in the atmosphere, with a smaller contribution from untagged sources (Southern Hemisphere, biogenic and oceanic sources, aircraft emissions). The "No-tag" background accounts on average for more than $50 \%$ of the total $\mathrm{CO}$, which is in the range found in previous $\mathrm{CO}$ budget studies (Granier et al., 1999; Horowitz et al., 2003; Pfister et al., 2004).

The $\mathrm{AVG}^{\text {RegionTime }}$ results show large contributions throughout all altitudes from BB and FF sources in Asia. FF Asian contributions tend to be larger at the higher altitudes, which is also the altitude range where Asian plumes were sampled on the June 22 flight (Figs. 2 and 3) whereas the Asian BB tracer peaks at lower altitudes. Analysis of the model tracer transport (not shown here) shows that for the FF Asian tracer, with sources mostly south of about $40 \mathrm{~N}$, the transport pathways are at more southern latitudes and higher altitudes, while most BB sources in Asia at this time of the year originate in northern Asia and those emissions are generally transported at higher latitudes and lower altitudes. We also see that US sources contribute to CO off the coast. The largest average contributions are seen at lower altitudes with FF US. Large contributions also come from the US fires (in the $\mathrm{AVG}^{\text {RegionTime, }}$, but not $\mathrm{AVG}^{\text {Region }}$ results). The US sources also add to the free tropospheric $(>2 \mathrm{~km})$ $\mathrm{CO}$. The influence of fresh fire plumes is most pronounced at altitudes above $1 \mathrm{~km}$ and below about $4 \mathrm{~km}$ indicating that these plumes are transported at low altitudes but are not efficiently mixed into the marine boundary layer over the distances and time scales considered here.

The combined variability of $\mathrm{CO}$ in $\mathrm{AVG}^{\text {RegionTime }}$ (as expressed by the standard deviation) is up to about $40 \mathrm{ppbV}$ $(\sim 30 \%)$ at the lower altitudes decreasing to about $11 \mathrm{ppbV}$ in the upper troposphere. A large part of the variability is driven by the US BB tracer, which dominates $\mathrm{AVG}^{\text {RegionTime }}$ variability at the lower altitudes and contributes significantly through the mid-troposphere. Significant contributions also come from the Asian BB tracer and the Asian FF tracer. "Notag/Photochemical" CO accounts for the major part of total $\mathrm{CO}$, but in comparison has a relatively small variability. Comparing $\mathrm{AVG}^{\text {Region }}$ to $\mathrm{AVG}^{\text {RegionTime }}$ at the higher altitude levels, we find an increased contribution and variability of Asian transport on the flight day compared to the temporal average, indicating that the flight day had an increased prevalence of plumes transported from Asia. We further find that the US BB tracer did not influence the selected region on the flight day, while the US FF influence on the flight day is comparable to the long-term sampling.

The analysis shows a significant influence of the wildfires in California, and since the June 2008 flight period was characterized by unusually intense fire activity, we compare and analyze the observations and model results with the fire 
influence removed, or at least greatly reduced. For the DC-8 flight track we use acetonitrile measurements together with model tracers for $\mathrm{CO}$ and $\mathrm{O}_{3}$ produced from fires in the US. We only include observations with measured acetonitrile $<0.25 \mathrm{ppbV}$ and model results when the relative contributions of the CO US fire tracers to total $\mathrm{CO}$ and of the $\mathrm{O}_{3}$ US Fire Tracer to total $\mathrm{O}_{3}$ are less than 5\%. Fire influence was negligible in the flight track model results and in $\mathrm{AVG}^{\text {Region }}$, but not in $\mathrm{AVG}^{\text {RegionTime }}$. Table 1 gives a summary of the free tropospheric source contributions and compares results with and without fire influence (filtering for fire influence reduces the number of points by about 5\%). Omitting results with US BB has only a small influence on the contributions from tracers other than the US BB tracer. US FF slightly decreases reflecting the mixed outflow of $\mathrm{FF}$ and $\mathrm{BB}$ pollution.

We also include the average source contributions when model results are considered only with a wind direction directed towards the continent to select only airmasses being transported towards the US. In this case, the average contribution of US BB is clearly lower, but still has a nonnegligible associated variability. This indicates that fresh fire plumes can be transported to the west off the coast followed by return to the continent. The US FF tracer changes little under this wind selection, which indicates that only a part of the US FF contribution to the boundary conditions is due to a direct recirculation of pollution. The $\mathrm{CO}$ lifetime is several weeks so it can be transported hemispherically, with US FF emissions entering the western boundary after "aroundthe-world" transport. Analysis of the spatial distributions of the model tracers (not shown here) support these transport patterns.

The results demonstrate that in choosing chemical boundary conditions for regional models the contributions from within the regional domain must be carefully considered. It should be noted that the fires in California started after 20 June so only parts of the considered time window potentially could have been impacted. Farther into an intense fire season, the fire emissions might have an even stronger influence. The results discussed here suggest that pollution from within the US can contribute to the "chemical inflow", both through direct recirculation of west coast emissions transported offshore and, at least for long-lived tracers, also through "around-the-world" transport. To capture these effects, it is important to ensure the highest possible consistency in emissions, transport and chemistry between the global and the regional model. Additionally, extending the domain of the regional model as far off the coast as possible will improve the model performance. The US contribution must also be considered when analyzing and designing observations for studying the chemical boundary conditions.

\subsubsection{Free tropospheric statistics}

We now evaluate how well the model reproduces the range and distribution of observed $\mathrm{CO}$ and $\mathrm{O}_{3}$ values, the low end ("background") of $\mathrm{CO}$ and $\mathrm{O}_{3}$, and especially the frequency of high concentrations ("plumes"). We first look at the free tropospheric statistics $(2-8 \mathrm{~km})$ to emphasize the free tropospheric transport. This also allows for a more direct comparison with TES retrievals (Sect. 3.3.1), which have low sensitivity near the surface, and with aircraft data over land (Sect. 3.2 and 3.3.2), which, especially at lower altitudes, might be influenced by local sources. Related percentiles for data sets with and without fire influence are specified in Table 2 .

The model generally predicts a larger number of low to moderate $\mathrm{CO}$ values but underestimates the upper limit and overestimates the lower limit of the $\mathrm{CO}$ distribution. Assuming the 10th percentile as representative for CO background concentrations, then the model overestimates the observed background of $79 \mathrm{ppbV}$ by about $15 \mathrm{ppbV}$. Omitting the fire influence in the $\mathrm{AVG}^{\text {RegionTime }}$ model results has little effect on the lower end of the distribution, but reduces the high end. However, also in this case the model underestimates the observed tail (Table 2). The low model bias for the 99th percentile is more pronounced compared to the 90th percentile, which is an indicator for the even stronger dilution of intense pollution plume events in the model.

The model also predicts a much narrower range of $\mathrm{CO}$ concentrations than observed. The 10th to 90th percentiles of the observations (no fire) span a range of $46 \mathrm{ppbV}$, while the model results along the flight track span a range of $27 \mathrm{ppbV}$. The corresponding ranges for $\mathrm{AVG}^{\text {Region }}$ and $\mathrm{AVG}^{\text {RegionTime }}$ (no fire) are $37 \mathrm{ppbV}$ and $24 \mathrm{ppbV}$, respectively; i.e. the model represents about half of the observed range of $\mathrm{CO}$ concentrations. Similar conclusions are reached if the 199\% range is considered (only 99th percentile is listed in Table 2). Overall the model results are biased high in CO compared to the observations. The mean observed concentration is $100 \pm 23 \mathrm{ppbV}$ compared to $109 \pm 12 \mathrm{ppbV}$ for the model flight track model results, $109 \pm 17 \mathrm{ppbV}$ for $\mathrm{AVG}^{\text {Region }}$ and $102 \pm 10 \mathrm{ppbV}$ for $\mathrm{AVG}^{\text {RegionTime }}$. The higher upper percentiles, mean and standard deviation for $\mathrm{AVG}^{\text {Region }}$ compared to $\mathrm{AVG}^{\text {RegionTime }}$ again support the finding that the 22 June flight day had a higher than average influence of pollution transport. The mean difference between the modeled and the observed flight data is $9 \pm 20 \mathrm{ppbV}(12 \pm 16 \%)$.

With regard to the $\mathrm{O}_{3}$ distribution, the model does underestimate the high end as well as median of the observed $\mathrm{O}_{3}$ distribution, while being biased high on the low end. The range of $\mathrm{O}_{3}$ (no fire) values spanned by the 10th-90th percentiles is $54 \mathrm{ppbV}$ in the observations and $25 \mathrm{ppbV}$ in the corresponding model results. The range for $\mathrm{AVG}^{\mathrm{Region}}$ model results is $29 \mathrm{ppbV}$ and for $\mathrm{AVG}^{\text {RegionTime }} 28 \mathrm{ppbV}$. Similar to CO, the model reflects about half of the observed $\mathrm{O}_{3}$ range.

Omitting fire data has a smaller effect on $\mathrm{O}_{3}$ than on $\mathrm{CO}$, because fresh fire plumes have high $\mathrm{CO}$ but not necessarily high $\mathrm{O}_{3}$ and also because the high end of the $\mathrm{O}_{3}$ distribution strongly reflects stratospheric influence. Overall the 
Table 2. Percentiles, mean and standard deviation for different data sets (2-8 km or $850-350 \mathrm{hPa})$. The second row, where given, gives results when US fire influenced data are omitted. The numbers in the furthest left column give the number of data points that went into the no-fire impacted statistics if filtering was applied.

\begin{tabular}{|c|c|c|c|c|c|c|c|c|c|c|}
\hline & \multicolumn{5}{|c|}{$\mathrm{CO}(\mathrm{ppbV})$} & \multicolumn{5}{|c|}{$\mathrm{O}_{3}(\mathrm{ppbV})$} \\
\hline & 10th & 50 th & 90th & 99th & Mean & 10th & 50 th & 90th & 99th & Mean \\
\hline \multirow{2}{*}{$\begin{array}{l}\text { DC-8 Obs Ocean } \\
n=105(101)\end{array}$} & 79 & 95 & 127 & 200 & $101 \pm 24$ & 37 & 64 & 91 & 109 & $65 \pm 19$ \\
\hline & 79 & 95 & 125 & 200 & $100 \pm 23$ & 36 & 64 & 90 & 109 & $64 \pm 19$ \\
\hline \multirow{2}{*}{$\begin{array}{l}\text { DC-8 MOZ Ocean } \\
n=105(101)\end{array}$} & 95 & 107 & 123 & 144 & $109 \pm 13$ & 46 & 56 & 70 & 73 & $57 \pm 10$ \\
\hline & 95 & 106 & 122 & 145 & $109 \pm 12$ & 45 & 56 & 70 & 73 & $56 \pm 10$ \\
\hline \multirow{2}{*}{$\begin{array}{l}\text { AVG }^{\text {Region }} \text { Ocean } \\
\text { Ocean } n=1209(1209)\end{array}$} & 93 & 104 & 130 & 171 & $109 \pm 17$ & 39 & 52 & 68 & 75 & $53 \pm 11$ \\
\hline & 93 & 104 & 130 & 170 & $109 \pm 17$ & 39 & 52 & 68 & 75 & $53 \pm 11$ \\
\hline \multirow{2}{*}{$\begin{array}{l}\text { AVG }^{\text {RegionTime }} \text { Ocean } \\
n=154752(148706)\end{array}$} & 92 & 100 & 119 & 154 & $104 \pm 14$ & 37 & 49 & 65 & 81 & $50 \pm 12$ \\
\hline & 92 & 100 & 116 & 137 & $102 \pm 10$ & 37 & 49 & 65 & 81 & $50 \pm 12$ \\
\hline \multirow{2}{*}{$\begin{array}{l}\text { DC-8 Land } \\
n=616(415)\end{array}$} & 78 & 98 & 206 & 449 & $125 \pm 77$ & 43 & 56 & 84 & 117 & $61 \pm 16$ \\
\hline & 75 & 93 & 121 & 171 & $95 \pm 21$ & 43 & 54 & 77 & 87 & $57 \pm 12$ \\
\hline \multirow{2}{*}{$\begin{array}{l}\text { DC-8 MOZ Land } \\
n=616(415)\end{array}$} & 95 & 105 & 149 & 250 & $115 \pm 36$ & 46 & 51 & 60 & 84 & $52 \pm 7$ \\
\hline & 94 & 101 & 116 & 162 & $104 \pm 12$ & 46 & 51 & 59 & 71 & $51 \pm 6$ \\
\hline \multirow{2}{*}{$\begin{array}{l}\mathrm{AVG}^{\text {Region }} \text { Land } \\
\text { Land } n=5559 \text { (5057) }\end{array}$} & 94 & 102 & 122 & 357 & $112 \pm 46$ & 40 & 50 & 60 & 81 & $50 \pm 9$ \\
\hline & 94 & 101 & 114 & 131 & $103 \pm 9$ & 40 & 50 & 59 & 80 & $50 \pm 9$ \\
\hline \multirow{2}{*}{$\begin{array}{l}\text { AVG }^{\text {RegionTime }} \text { Land } \\
\text { Land } n=178314 \text { (149580) }\end{array}$} & 94 & 102 & 138 & 378 & $116 \pm 54$ & 41 & 51 & 65 & 85 & $52 \pm 10$ \\
\hline & 93 & 100 & 114 & 137 & $102 \pm 9$ & 41 & 50 & 62 & 79 & $51 \pm 10$ \\
\hline TES (n=549) & 86 & 106 & 128 & 163 & $107 \pm 17$ & 43 & 54 & 68 & 84 & $55 \pm 11$ \\
\hline MOZART_AK $(n=549)$ & 94 & 106 & 130 & 140 & $109 \pm 13$ & 39 & 47 & 54 & 66 & $47 \pm 7$ \\
\hline \multirow{2}{*}{$\begin{array}{l}\text { MOZART_true } \\
n=549(548)\end{array}$} & 93 & 102 & 137 & 151 & $109 \pm 17$ & 35 & 49 & 71 & 80 & $51 \pm 14$ \\
\hline & 93 & 102 & 138 & 151 & $109 \pm 17$ & 35 & 49 & 70 & 81 & $51 \pm 14$ \\
\hline \multirow{2}{*}{$\begin{array}{l}\text { MOZART_region } \\
n=1068408(1054457)\end{array}$} & 92 & 101 & 127 & 151 & $106 \pm 14$ & 23 & 44 & 66 & 91 & $44 \pm 17$ \\
\hline & 92 & 101 & 127 & 150 & $106 \pm 14$ & 23 & 44 & 66 & 92 & $44 \pm 17$ \\
\hline $\begin{array}{l}\text { MOZAIC } \\
n=2824 ; \mathrm{O}_{3} n=1865\end{array}$ & 77 & 104 & 131 & 156 & $105 \pm 20$ & 38 & 62 & 85 & 110 & $62 \pm 19$ \\
\hline Ozonesonde $(n=7374)$ & & & & & & 37 & 58 & 86 & 117 & $61 \pm 20$ \\
\hline MOZ_AVERAGE & 99 & 103 & 110 & 114 & $104 \pm 4$ & 45 & 50 & 56 & 61 & $50 \pm 4$ \\
\hline
\end{tabular}

model underestimates $\mathrm{O}_{3}$. The mean observed $\mathrm{O}_{3}$ concentration is $64 \pm 19 \mathrm{ppbV}$ compared to $56 \pm 10 \mathrm{ppbV}$ for the modeled flight track model results, $53 \pm 11$ for $\mathrm{AVG}^{\text {Region }}$ and $50 \pm 12 \mathrm{ppbV}$ for $\mathrm{AVG}^{\text {RegionTime }}$. $\mathrm{AVG}^{\text {Region }}$ is again somewhat enhanced over $\mathrm{AVG}^{\text {RegionTime }}$. The average difference for modeled and observed flight track data is $-8 \pm 18 \mathrm{ppbV}$ $(-5 \pm 33 \%)$.

\subsubsection{Statistics for boundary layer air}

Marine boundary layer air (MBL) influences the surface air over California (Parrish et al., 2010), and for this reason we present an analysis of the $0-1 \mathrm{~km}$ altitude range for the above data sets. Table 3 lists percentiles of $\mathrm{CO}$ and $\mathrm{O}_{3}$ concentrations and Table 4 and Fig. 4 gives the average source contributions based on model CO tracers. Compared to the free troposphere, the tagged source analysis in the boundary layer indicates a somewhat higher contribution of no-tag/photochemical CO and enhanced contribution of BB Asia and slightly reduced contribution of FF Asia. The latter is in relation to the transport altitudes of Asian tracers discussed in Sect. 3.3.1.

As reflected in the observed and modeled vertical profile characteristics shown in Fig. 2, MBL air has clearly reduced $\mathrm{O}_{3}$ concentrations. The observed median concentrations are $31 \mathrm{ppbV}$ compared to $64 \mathrm{ppbV}$ in the FT and the modeled median concentrations are about $20-30 \mathrm{ppbV}$ compared to $50-60 \mathrm{ppbV}$. Overall the model underestimates $\mathrm{O}_{3}$ 
Table 3. Percentiles, mean and standard deviation for DC- 8 Ocean Data Sets and ozonesonde data for the $0-1 \mathrm{~km}$ altitude range. The second row, where given, gives results when US fire influenced data are omitted. The numbers in the furthest left column give the number of data points that went into the no-fire impacted statistics if filtering was applied.

\begin{tabular}{l|cccc|cccc}
\hline & \multicolumn{4}{|c|}{ CO (ppbV) } & \multicolumn{4}{c}{$\mathrm{O}_{3}$ (ppbV) } \\
& 10 th & 50 th & 90 th & Mean & 10 th & 50 th & 90 th & Mean \\
\hline DC-8 Obs Ocean & 89 & 93 & 102 & $94 \pm 5$ & 26 & 31 & 43 & $31 \pm 7$ \\
$n=31$ & 89 & 94 & 102 & $94 \pm 5$ & 23 & 31 & 43 & $31 \pm 7$ \\
\hline DC-8 MOZ Ocean & 97 & 101 & 110 & $103 \pm 4$ & 16 & 21 & 33 & $22 \pm 7$ \\
$n=31$ & 97 & 102 & 110 & $103 \pm 4$ & 16 & 21 & 33 & $23 \pm 7$ \\
\hline AVG $^{\text {Region Ocean }}$ & 97 & 101 & 115 & $103 \pm 9$ & 16 & 21 & 40 & $24 \pm 9$ \\
$n=1028$ & 97 & 101 & 116 & $103 \pm 9$ & 16 & 21 & 40 & $24 \pm 9$ \\
\hline AVG $^{\text {RegionTime Ocean }}$ & 96 & 113 & 143 & $118 \pm 18$ & 18 & 28 & 45 & $30 \pm 11$ \\
$n=122027$ & 96 & 113 & 142 & $117 \pm 17$ & 17 & 27 & 44 & $30 \pm 11$ \\
\hline Sonde $(n=1304)$ & & & & 16 & 28 & 45 & $30 \pm 29$ \\
\hline
\end{tabular}

Table 4. Average CO Source Contributions for $\mathrm{AVG}^{\text {RegionTime }}$ Ocean and the $0-1 \mathrm{~km}$ altitude range. Units are ppbV CO.

\begin{tabular}{lccc}
\hline & Ocean ALL & Ocean noFire & $\begin{array}{c}\text { Ocean ALL } \\
\text { WindDir 200-340 deg }\end{array}$ \\
\hline NoTag & $71.9 \pm 6.9$ & $71.7 \pm 6.9$ & $69.2 \pm 5.2$ \\
BB_US & $1.2 \pm 5.5$ & $0.3 \pm 0.4$ & $1.5 \pm 4.4$ \\
BB_AKCan & $0.0 \pm 0.0$ & $0 \pm 0$ & $0.0 \pm 0.0$ \\
BB_Asia & $19.0 \pm 6.4$ & $19.1 \pm 6.5$ & $16.4 \pm 4.1$ \\
BB_EuAf & $0.7 \pm 0.1$ & $0.7 \pm 0.1$ & $0.6 \pm 0.1$ \\
BB_Cam & $0.9 \pm 0.4$ & $0.9 \pm 0.4$ & $0.9 \pm 0.5$ \\
FF_US & $3.5 \pm 3.2$ & $3.1 \pm 2.2$ & $3.4 \pm 4.0$ \\
FF_AKCan & $0.3 \pm 0.1$ & $0.3 \pm 0.1$ & $0.3 \pm 0.1$ \\
FF_Asia & $15.1 \pm 2.5$ & $15.2 \pm 2.6$ & $14.2 \pm 1.5$ \\
FF_EuAf & $4.1 \pm 1.2$ & $4.1 \pm 1.2$ & $3.5 \pm 0.8$ \\
FF_Cam & $0.5 \pm 0.2$ & $0.5 \pm 0.2$ & $0.4 \pm 0.2$ \\
\hline
\end{tabular}

concentrations in the marine boundary layer: mean $\mathrm{O}_{3}$ concentrations for the observed and modeled flight track data, $\mathrm{AVG}^{\text {Region }}$ and $\mathrm{AVG}^{\text {RegionTime }}$ are $31 \pm 7 \mathrm{ppbV}, 23 \pm 7 \mathrm{ppbV}$, $24 \pm 9 \mathrm{ppbV}$ and $30 \pm 11 \mathrm{ppbV}$, respectively.

The vertical gradient is less pronounced for $\mathrm{CO}$ and median CO concentrations are comparable between the free tropospheric (FT) and the boundary layer air. As in the FT, the model is biased high for $\mathrm{CO}$, but for both $\mathrm{CO}$ and $\mathrm{O}_{3}$ the model shows a better representation of the observed variability in the boundary layer. This implies that it is to a large extent FT plume transport that is underestimated in the model.

\subsection{Chemical BC from ARCTAS-CARB flights over land and model results}

Observations over ocean are generally less common than observations over land and frequently vertical soundings in the free troposphere over land are used for characterizing pollution inflow. Here we examine ARCTAS-CARB aircraft data and model simulations over land to evaluate the representativeness of the continental free troposphere for inflow. Similar to the analysis of ocean data we consider statistics of observed and modeled flight track data, statistics over a larger region for the flight days ( $\mathrm{AVG}^{\text {Region}} ; 18,20,22$ and 24 June at 18:00 UTC) and statistics over a larger region and larger temporal average (AVG ${ }^{\text {RegionTime}} ; 15-30$ June). The flight tracks and larger region are shown in Fig. 1 (blue squares). The influence of the California wildfires is significant for observations over land and, unless stated otherwise, we only discuss data filtered for fire influence following the same criteria as for the ocean data.

A comparison of observed and modeled vertical profiles for $\mathrm{CO}, \mathrm{O}_{3}$ and PAN is shown in Fig. 5. The model captures vertical gradients and overall concentrations well. Contrary to ocean data we see that concentrations generally increase in magnitude and variability towards the surface due to the influence of local sources. Elevated $\mathrm{CO}, \mathrm{O}_{3}$ and PAN concentrations observed at around $6 \mathrm{~km}$ are fairly well reflected in the model results. As for the ocean data, the model in the FT has a high bias in $\mathrm{CO}$ and a low bias in $\mathrm{O}_{3}$. The mean difference in FT concentrations between modeled and observed flight track data is $8 \pm 16 \mathrm{ppbV}(12 \pm 17 \%)$ for $\mathrm{CO}$ and $-5 \pm 11 \mathrm{ppbV}(-6 \pm 18 \%)$ for $\mathrm{O}_{3}$.

Vertical profiles of the $\mathrm{CO}$ tagged tracer contributions over land are shown in Fig. 6. In this case we include all data without filtering for fire influence to demonstrate how important the influence of local emissions can be. $\mathrm{CO}$ has a first-order linear chemistry and CO tracer contributions can be interpreted as additive terms. The results show that local (US) sources have a significant influence at the lower altitude levels, but overall show little influence above about 

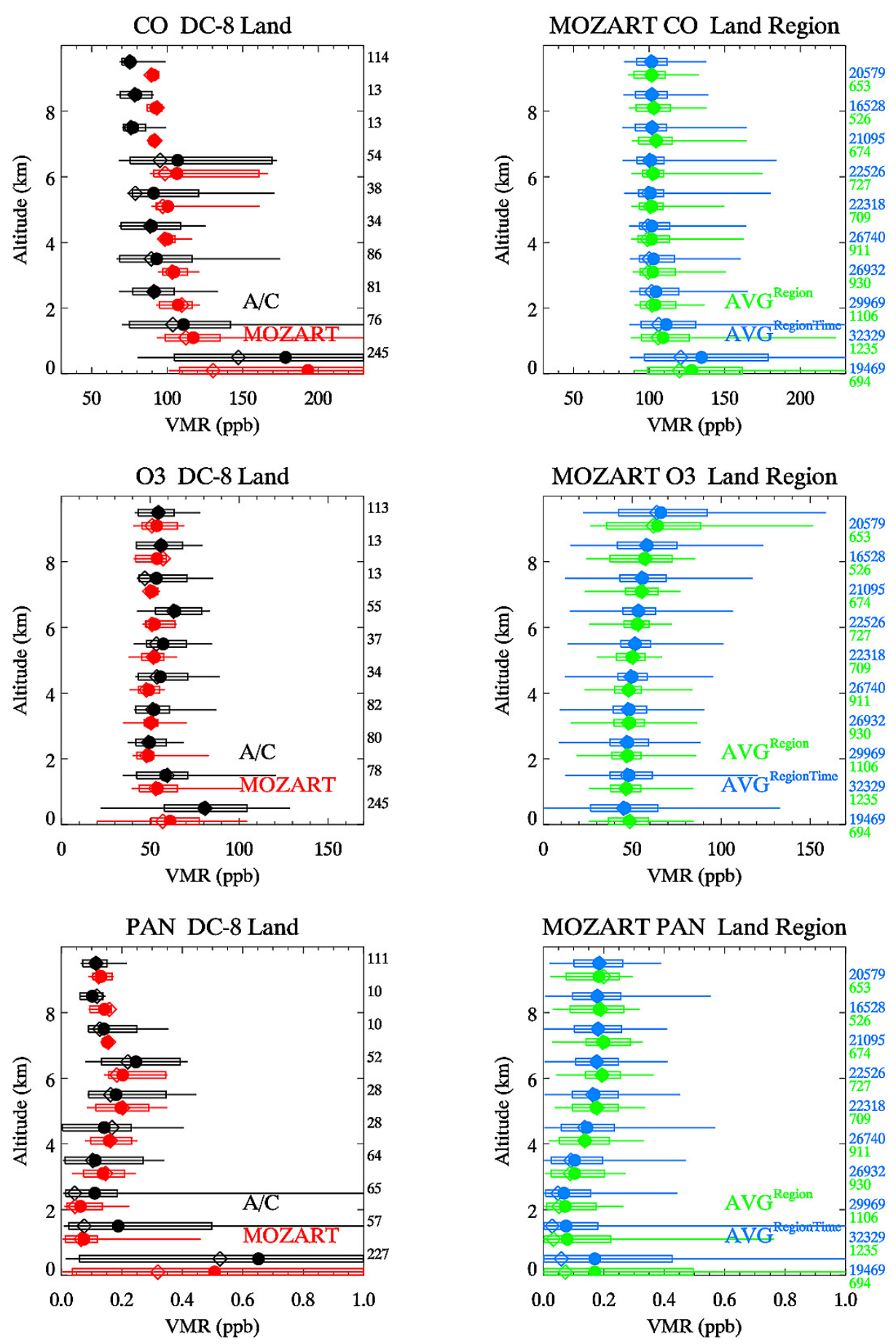

Fig. 5. As Fig. 2 but for DC-8 Land data sets and the data have been filtered for fire influence.

$4 \mathrm{~km}$. As seen from Table 5, where we list mean FT tracer contributions for selections with and without fire filtering, it can be noted that filtering for fire influence also reduces the FF US contributions in the FT from $3.7 \pm 4.7 \mathrm{ppbV}$ to $2.3 \pm 1.8 \mathrm{ppbV}$. This filtering has little effect on contributions from other tracers.
Aside from a slightly enhanced influence of local emissions, which can be significant in case of extreme events such as the wildfires, the FT over land shows fairly similar concentrations and variability compared to the ocean region (Table 2). FT concentrations over land are somewhat smaller compared to ocean for the flight day(s), which again 

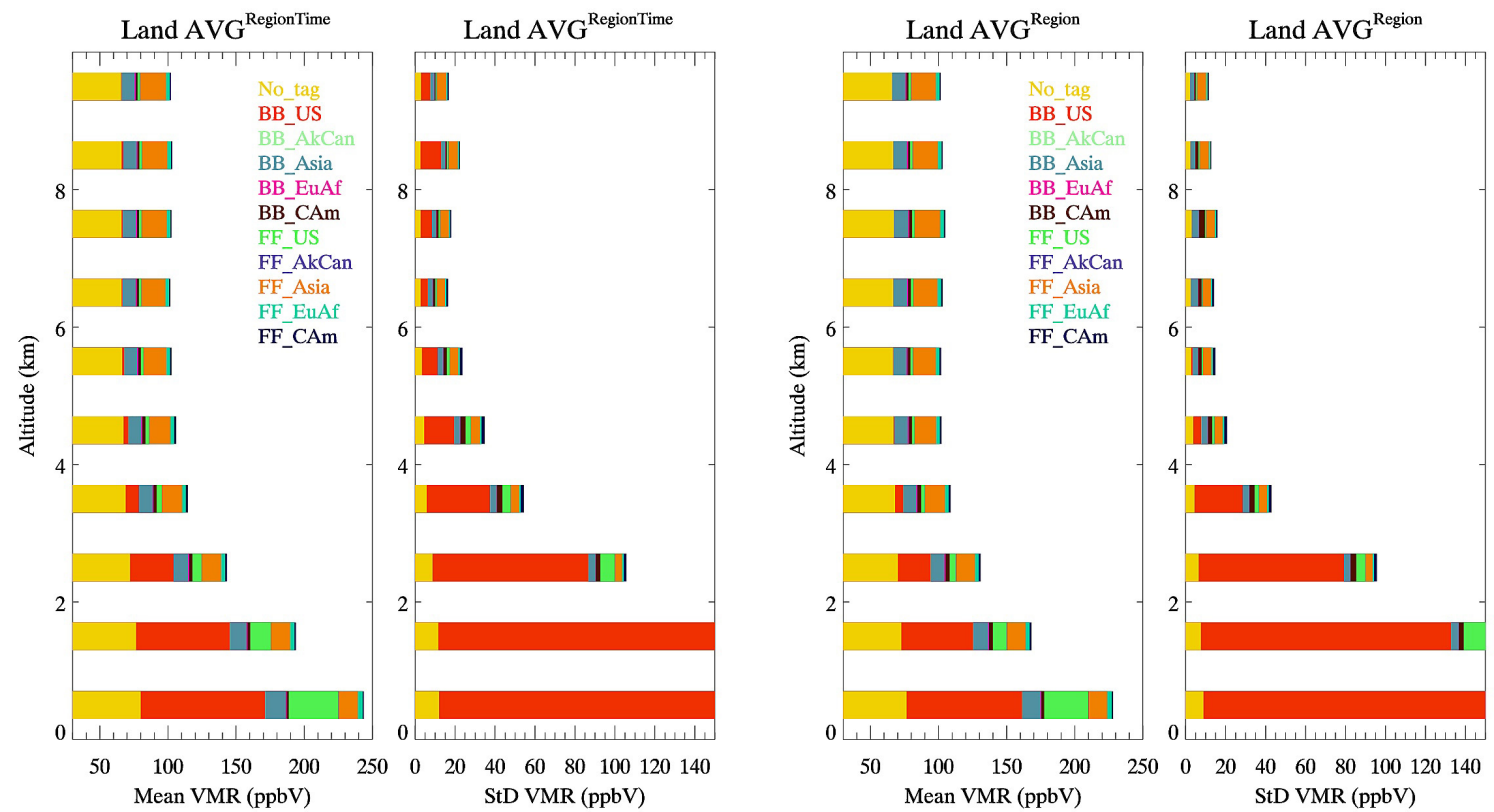

Fig. 6. As Fig. 4 but for AVGRegionTime and AVGRegion Land Data Sets.

indicates that the ocean flight was conducted on a day with above average pollution transport. Average FT CO concentrations over land are $95 \pm 21 \mathrm{ppbV}$ and $104 \pm 12 \mathrm{ppbV}$ for observed and modeled flight track data, $103 \pm 9 \mathrm{ppbV}$ for $\mathrm{AVG}^{\text {Region }}$ and $102 \pm 9 \mathrm{ppbV}$ for $\mathrm{AVG}^{\text {RegionTime }}$. Average $\mathrm{O}_{3}$ concentrations are $57 \pm 12 \mathrm{ppbV}, 51 \pm 6 \mathrm{ppbV}, 50 \pm 9 \mathrm{ppbV}$, and $51 \pm 10 \mathrm{ppbV}$, respectively. The flight track model results are underestimating the observed variability by a factor of 2. The increased variability in $\mathrm{O}_{3}$ for $\mathrm{AVG}^{\text {Region }}$ and $\mathrm{AVG}^{\text {RegionTime }}$ suggests that, at least for $\mathrm{O}_{3}$, the flight sampling was less representative for the large-scale variability.

\subsection{Chemical boundary conditions from other data sets}

As we have shown in the previous analysis, the chemical inflow into the US West Coast is highly variable on spatial and temporal scales. Here we extend our analysis to three other observational data sets in order (1) to increase the sample size of observed chemical inflow conditions and gain a more complete picture of the existing variability, (2) to evaluate the boundary conditions flight for its representativeness in the context of other observations, and (3) to provide further evaluation of the modeled magnitude and variability. Additional data sets include $\mathrm{CO}$ and $\mathrm{O}_{3}$ retrievals from the Tropospheric Emissions Spectrometer (TES) onboard the NASA EOS Aura satellite, $\mathrm{CO}$ and $\mathrm{O}_{3}$ aircraft measurements from the MOZAIC program on flights into Los Angeles, California and Portland, Oregon, and $\mathrm{O}_{3}$ sonde launches at Trinidad Head.
Table 5. Average CO Source Contributions for $\mathrm{AVG}^{\text {RegionTime }}$ Land and the $2-8 \mathrm{~km}$ altitude range. Units are ppbV CO.

\begin{tabular}{lrr}
\hline & Land ALL & Land noFire \\
\hline NoTag & $68.4 \pm 6.3$ & $66.9 \pm 3.9$ \\
BB_US & $11.4 \pm 45.1$ & $0.5 \pm 0.8$ \\
BB_AKCan & $0.0 \pm 0.0$ & $0.0 \pm 0.0$ \\
BB_Asia & $9.9 \pm 3.0$ & $9.6 \pm 3.0$ \\
BB_EuAf & $0.8 \pm 0.1$ & $0.9 \pm 0.1$ \\
BB_Cam & $2.1 \pm 2.2$ & $2.2 \pm 2.3$ \\
FF_US & $3.7 \pm 4.7$ & $2.3 \pm 1.8$ \\
FF_AKCan & $0.1 \pm 0.1$ & $0.1 \pm 0.1$ \\
FF_Asia & $15.8 \pm 4.4$ & $15.9 \pm 4.6$ \\
FF_EuAf & $2.7 \pm 0.8$ & $2.7 \pm 0.8$ \\
FF_Cam & $1.3 \pm 1.3$ & $1.4 \pm 1.4$ \\
\hline
\end{tabular}

\subsubsection{TES satellite retrievals}

For the analysis of TES data we collect all TES retrievals for 15-30 June 2008 over the region $130-150 \mathrm{~W}$ and 30 $43 \mathrm{~N}$. Compared to the larger region chosen for the analysis of the ARCTAS/CARB aircraft data, we extend and shift the TES region towards the West to emphasize the influence of long-range transport and minimize possible influence from the California fires (Fig. 1). Table 1 lists the modeled average $\mathrm{CO}$ tracer contributions for the TES region, which shows overall similar contributions, but a reduced, though still present, influence of US BB and somewhat increased influence of the Asian tracers. 

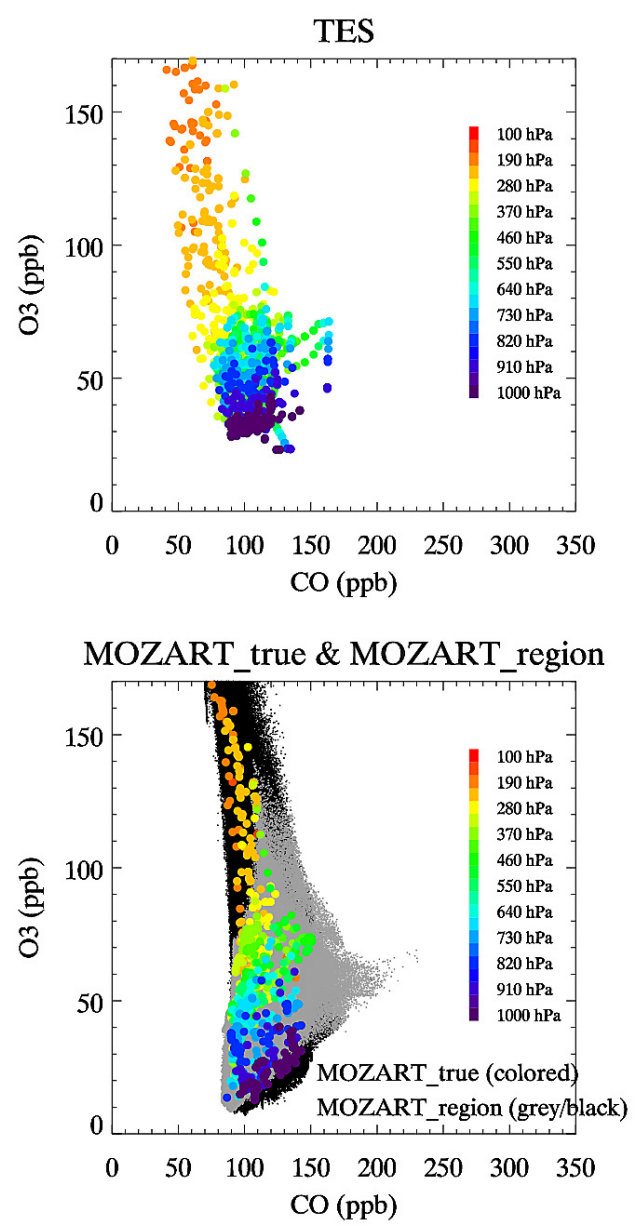
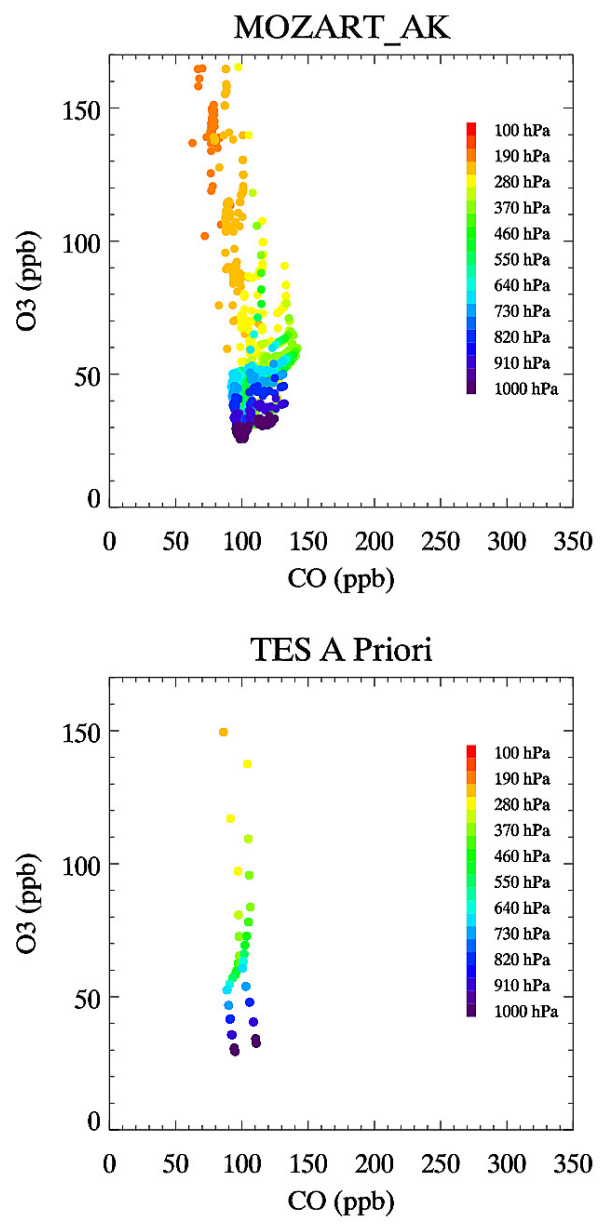

Fig. 7. As Fig. 3, but for TES CO and $\mathrm{O}_{3}$ retrievals. Retrievals over Ocean (130-150 W, 30-45 N) for 15-30 June 2008. MOZART has been interpolated to the time, location and pressure grid (MOZART_true) and convolved with the TES Averaging Kernels (MOZART_AK). The bottom left panel further includes MOZART data for the entire region and time period with data within the 850-350 mbar range colored in gray (MOZART_region). The bottom right panel shows scatter plots for the TES a priori $\mathrm{CO}$ and $\mathrm{O}_{3}$ profiles.

For the following analysis only daytime TES retrievals with a degree of freedom of signal (DFS) larger than 1 and an average cloud optical depth $<0.1$ are included. Further selection criteria include a retrieval quality flag of 1 and a check of the $\mathrm{O}_{3} \mathrm{C}$-Curve quality flag to eliminate unphysical $\mathrm{O}_{3}$ retrievals (Osterman et al., 2009). In total this gives 61 coincident $\mathrm{CO}$ and $\mathrm{O}_{3}$ profiles. Interpretation of satellite retrievals is not as straightforward as for in-situ measurements. The retrieved profiles, while reported at specific vertical levels, represent averages over a broad range of the atmosphere with the vertical sensitivity expressed by the averaging kernels. To present the results in a manner comparable to the DC-8 data, we include in the following analysis the reported 11 retrieval levels between $850-350 \mathrm{hPa}$. However, it must be kept in mind that the retrievals have about 1-2 DFS and therefore the vertical levels are not independent of each other.

Results for $\mathrm{CO}$ to $\mathrm{O}_{3}$ relationships, similar to those shown for the DC-8 aircraft data in Fig. 3, are shown in Fig. 7. In comparing the two figures it must be kept in mind that
TES $\mathrm{CO}$ and $\mathrm{O}_{3}$ retrievals have a similar, but not identical, vertical sensitivity, which to some extent can distort the vertical correlations. We display the relationships for the TES retrievals and time/and space interpolated MOZART results with the TES averaging kernels and a priori applied (MOZART_AK). We further show the raw MOZART results for $850-350 \mathrm{hPa}$ interpolated to the time and location of the TES retrievals but without consideration of the averaging kernels (MOZART_true), which are overlaid on the MOZART $\mathrm{CO}$ and $\mathrm{O}_{3}$ results for the TES region and 15-30 June time period (MOZART_region). The relationship for the TES a priori $\mathrm{CO}$ and $\mathrm{O}_{3}$ profiles is also shown to provide insight into the underlying variability introduced into the retrievals by a time and space varying a priori. In both TES and MOZART_AK the range and variability of $\mathrm{CO}$ and $\mathrm{O}_{3}$ results are significantly increased over the underlying a priori information, confirming that the retrieved variability reflects information about the atmospheric concentrations, as expected from the data selection criteria. 


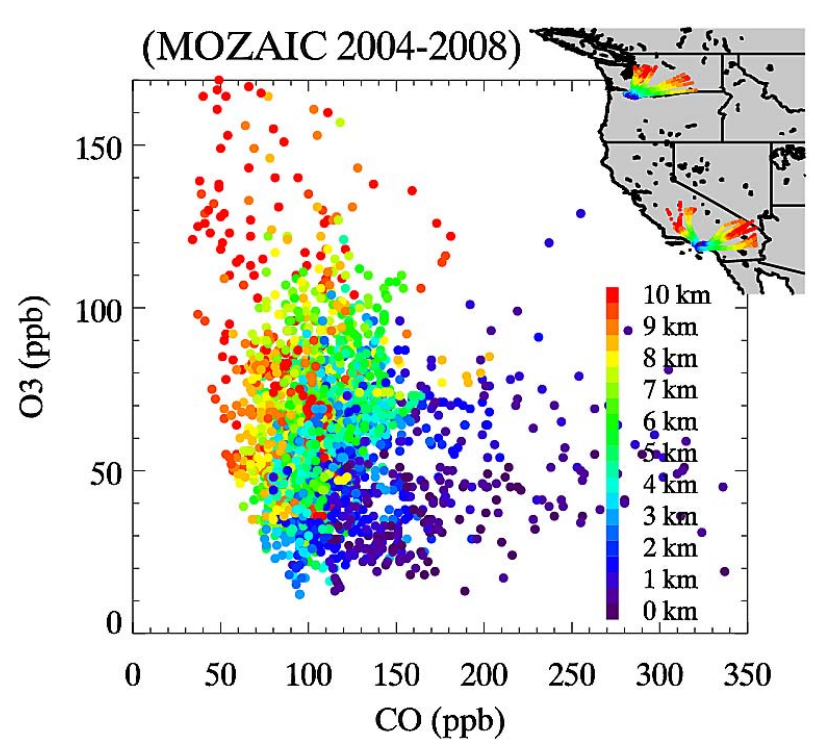

Fig. 8. As Fig. 3 but for MOZAIC CO and $\mathrm{O}_{3}$ data. The location of the MOZAIC profile measurements for June and July of 2004-2008 is shown in the map.

Following the analysis of the ARCTAS-CARB aircraft data, we also list percentiles for TES and corresponding model results in Table 2. Lacking observational evidence, we do not list fire-filtered statistics for TES retrievals and corresponding MOZART_AK results, but do so for MOZART_true and MOZART_region following the same filtering of model results as before. Fires have a small influence on the model statistics for TES sampling. The TESMOZART comparison leads to conclusions similar to those from the analysis of the aircraft data, even though the TES sensitivity has a smoothing effect on the measured and modeled values.

The model represents the main correlations seen in the TES data, but shows a smaller range, less variability and misses some of the retrievals with increased $\mathrm{CO}$ and $\mathrm{O}_{3}$. Overall the model, in agreement with the previous evaluation results, shows a mean positive bias compared to the TES $\mathrm{CO}$ retrievals of $2 \pm 15 \mathrm{ppbV}(3 \pm 14 \%)$ and a mean negative bias compared to the TES $\mathrm{O}_{3}$ retrievals of $-8 \pm 10 \mathrm{ppbV}$ $(-11 \pm 21 \%)$. The smoothing effect of the TES operator reduces the variability from $17 \mathrm{ppbV}$ to $13 \mathrm{ppbV}$ for $\mathrm{CO}$ and from $14 \mathrm{ppbV}$ to $7 \mathrm{ppbV}$ for $\mathrm{O}_{3}$. Comparing MOZART_true to the sampling for the entire region (MOZART_region) we see in the latter more elevated $\mathrm{CO} / \mathrm{O}_{3}$ plumes (Fig. 7). In a statistical sense (Table 2), however, these points have small weight and the statistics for the TES sampling gives an overall good representation of the temporal and spatial average with comparable means and medians for $\mathrm{CO}$, but somewhat enhanced $\mathrm{O}_{3}$ mean and medians.

\subsubsection{MOZAIC aircraft data and ozone sonde profiles}

We analyze MOZAIC CO and $\mathrm{O}_{3}$ aircraft data over California as an additional diagnostic for the representativeness of the ARCTAS/CARB boundary conditions flight. MOZAIC profiles over California are rare and to increase the sample size we look at all MOZAIC profiles collected in June or July during 2004-2008. In total we have 100 profiles, split about evenly between Portland and Los Angeles. For the Trinidad Head ozonesonde data we include all launches during June and July over the 10-year period 2000-2009. In total this gives 123 profiles. A time and space interpolated comparison of MOZAIC and ozonesonde data with model results is not included, because the simulations do not cover the measurement time period.

A scatter plot for the $\mathrm{CO}-\mathrm{O}_{3}$ relationships from MOZAIC data for $2-8 \mathrm{~km}$ is shown in Fig. 8 and the locations of the available profiles over Los Angeles and Portland are also illustrated. The related percentiles are listed in Table 2. The MOZAIC data show a larger number of data points with a strong increase in $\mathrm{CO}$ and moderate increase in $\mathrm{O}_{3}$ representative of fresh plumes. This is expected as the low altitude MOZAIC data are sampled over land on approach to airports in populated areas. Most of the fresh plumes were encountered at low altitudes, but there are a few points above $2 \mathrm{~km}$ reflecting fresh pollution characteristics (light blue points in Fig. 8). Overall, fresh continental pollution should have little impact on free tropospheric statistics. Some data points replicate the correlations of moderate $\mathrm{CO}$ and strong $\mathrm{O}_{3}$ increases as were seen in the DC-8 sampling, but at even higher altitudes.

Free tropospheric statistics for MOZAIC $\mathrm{CO}$ and MOZAIC and ozonesonde concentrations are listed in Table 2. Both data sets reflect the large variability that was seen in the previous datasets. The range spanned by the MOZAIC data (10-90\%) for CO is $54 \mathrm{ppbV}$, which is comparable to that sampled by the DC- 8 over the ocean on 22 June ( $49 \mathrm{ppbV})$. Also the percentiles are roughly comparable. Mean FT concentrations for MOZAIC CO data are $105 \pm 20 \mathrm{ppbV}$. A comparison of the very high CO data between the MOZAIC and the DC-8 ocean data sets confirms the exceptionally high plume values that were measured during the ARCTAS-CARB Boundary Leg Flight. The DC-8 Ocean 90th percentile is by about $50 \mathrm{ppbV}$ higher and the data set also has an enhanced frequency of high plumes: 3 out of 101 (3\%) DC-8 Ocean observations have CO values larger than $170 \mathrm{ppbv}$ and one observation $>200 \mathrm{ppbv}$ compared to the MOZAIC data set with 4 out of $2824(0.1 \%)$ $\mathrm{CO}$ values $>170 \mathrm{ppbV}$ and the largest value not exceeding $190 \mathrm{ppbV}$. High value frequencies for the DC-8 Land data set with fire influence removed are also smaller compared to the Ocean flight: the 99th percentile is lower by $30 \mathrm{ppbV}$ and 7 out of $415(2 \%) \mathrm{CO}$ values are $>170 \mathrm{ppbV}$. For the land data set the maximum observed value is $175 \mathrm{ppbV}$. 

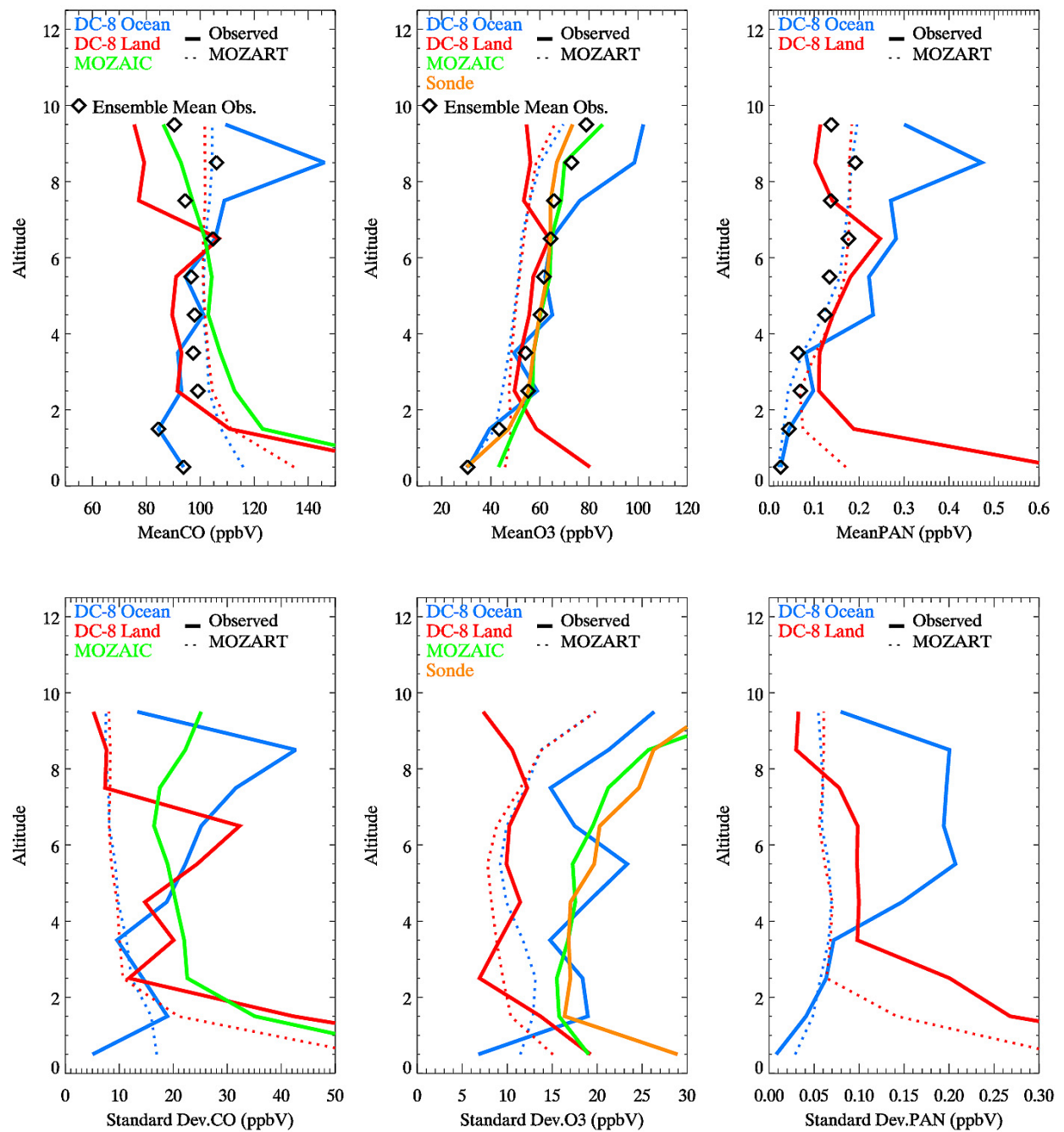

Fig. 9. Mean and standard deviation of vertical profiles for $\mathrm{CO}, \mathrm{O}_{3}$ and PAN from the different data sets DC8-Ocean (blue), DC-8 Land (red), MOZAIC (green) and ozonesondes (orange). Observations are shown in thick solid lines, and MOZART regional averages (AVGRegionTime) in dotted lines. The ensemble mean observed profile is denoted by symbols. For altitudes $<2 \mathrm{~km}$ the ensemble mean is derived from DC-8 Ocean and ozonesonde data only. Except for MOZAIC and sonde data, the data have been filtered for fire influence.

The 10-90\% range for $\mathrm{O}_{3}$ is $47 \mathrm{ppbV}$ for MOZAIC and $49 \mathrm{ppbV}$ for the sonde data, which is similar to the DC-8 sampling $(54 \mathrm{ppbV})$. Median and mean concentrations are slightly lower compared to DC-8 Ocean data, and closer to DC-8 Land sampling. Mean FT concentrations for MOZAIC $\mathrm{O}_{3}$ are $62 \pm 19 \mathrm{ppbV}$ and $61 \pm 20 \mathrm{ppbV}$ for the ozonesonde. Due to the pristine location of Trinidad Head, we also assess the sonde profiles at low altitudes for their representativeness of background concentrations and marine air. As shown in Table 3, the ozonesonde statistics over the $0-1 \mathrm{~km}$ altitude range are similar to the mean and median statistics calculated for the DC-8 Ocean data set. This confirms that Trinidad Head is a well-suited location for detecting background conditions and the value of using sonde measurements in examining inflow.

\subsection{Average Chemical BC from in-situ measurements and MOZART}

In Fig. 9 we combine the mean and standard deviation of the vertical distribution of $\mathrm{CO}, \mathrm{O}_{3}$ and PAN observations and model results for DC-8 flights over ocean and over land, $\mathrm{AVG}^{\text {RegionTime }}$ model results for the ocean and land region, MOZAIC aircraft data, and Trinidad Head ozonesonde profiles. We do not include TES data because of their limited vertical resolution. It becomes quite clear that chemical boundary conditions can by no means be envisioned as time and/or space invariant concentrations. The 1-km mean FT observations (similar conclusions are drawn from median statistics) vary by up to about $40 \mathrm{ppbV}$ in $\mathrm{CO}, 20 \mathrm{ppbV}$ in $\mathrm{O}_{3}$ and $0.2 \mathrm{ppbV}$ in PAN; the standard deviations for the individual data sets are about the same magnitude, and 


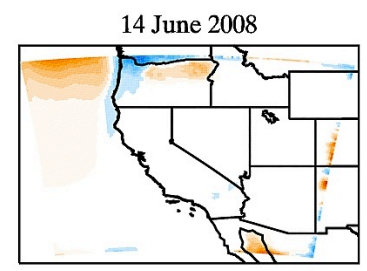

18 June 2008

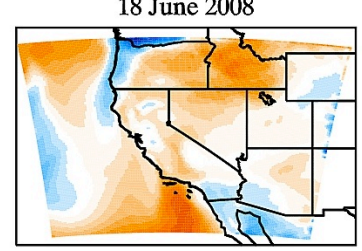

22. June 2008

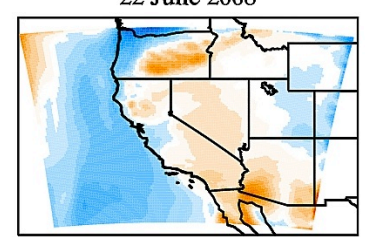

26 June 2008

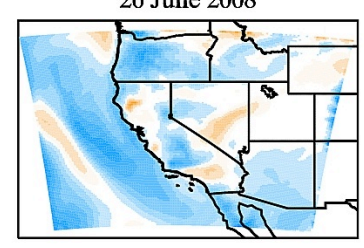

Surface O3 Average Difference (ppbV) ( Daily)

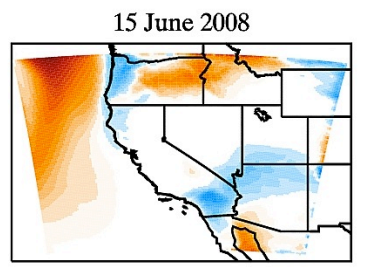

19 June 2008

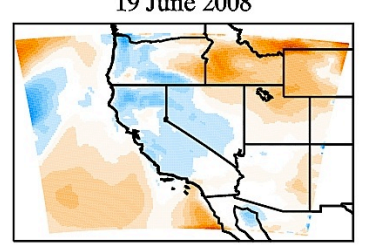

23 June 2008

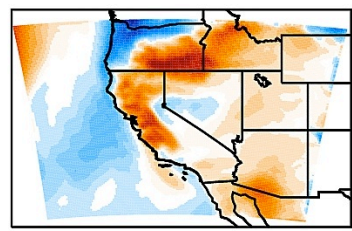

27 June 2008

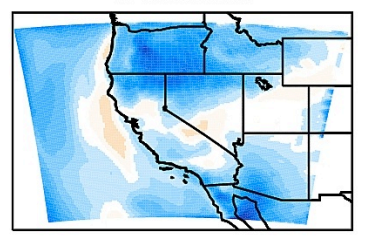

$-30$

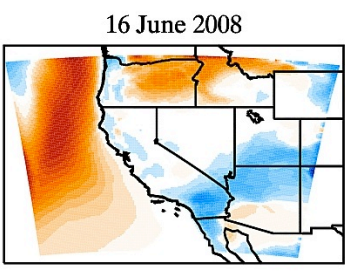

20 June 2008

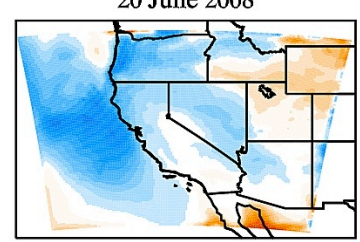

24 June 2008

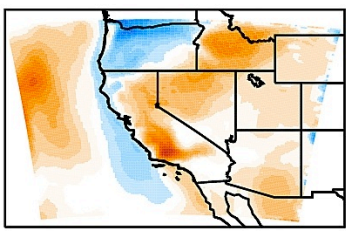

28 June 2008

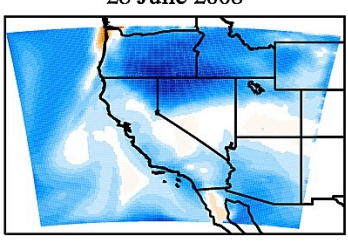

3

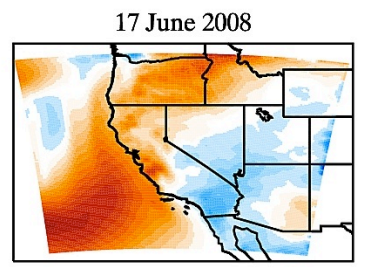

21 June 2008

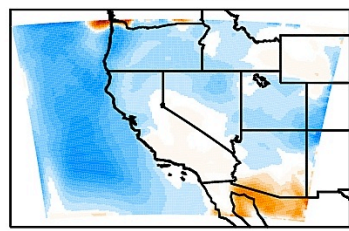

25 June 2008

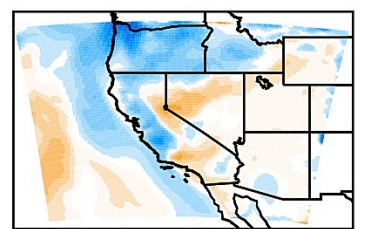

29 June 2008

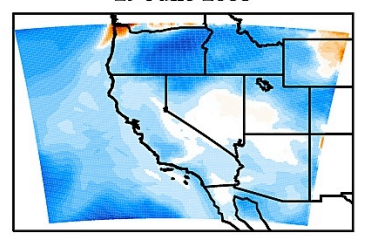

12

15

Fig. 10. Daily average difference in surface $\mathrm{O}_{3}(\mathrm{ppbV})$ between the WRF-Chem simulations with temporally varying and with temporally averaged chemical boundary conditions (variable BC minus mean BC).

clearly higher for observations compared to the model. The high concentrations at high altitudes for the DC-8 ocean flight are exceptional, and this supports our previous conclusion that the DC- 8 boundary conditions flight captured a more pronounced episode of long-range pollution transport than is usual. Aside from the lowermost altitudes, the aircraft measurements over land show no significant bias compared to the ocean data, again confirming that free tropospheric observations over land may be considered as representative of pollution inflow as long as caution is taken not to interpret lofted local pollution as pollution inflow.

We include in the graphs also the ensemble mean of all observational data sets. For the lowest $2 \mathrm{~km}$ we consider the DC-8 ocean data set and MOZAIC data only to avoid the influence of local pollution sources. For regional models, which are not designed to incorporate time and space varying boundary conditions or if boundary conditions from global models are not available with sufficient confidence, we suggest this ensemble mean might be used for a proper approximation of average inflow conditions. The ensemble mean does replicate vertical profiles typical for air masses over ocean, i.e. little vertical variability in $\mathrm{CO}$ and decreas- ing concentrations towards the surface for $\mathrm{O}_{3}$ and PAN. The average "background" conditions for $\mathrm{CO}$ are on the order of $100 \mathrm{ppbV}$, for $\mathrm{O}_{3}$ on the order of $25 \mathrm{ppbV}$ near the surface increasing to $55 \mathrm{ppbV}$ in the mid-troposphere, and for PAN about $0.02 \mathrm{ppbV}$ at the surface approaching $0.2 \mathrm{ppbV}$ at altitudes of $6 \mathrm{~km}$ and higher.

\section{Influence of the variability in chemical $\mathrm{BC}$ in a regional model}

The previous analysis demonstrates the large temporal and spatial variability that exists in the chemical inflow entering the US West Coast; here we examine how this variability influences surface concentrations over the continent. We use the MOZART simulations as boundary conditions for regional simulations with WRF-Chem and perform two sets of simulations. In the first ("Variable BC") the 3-hourly output fields from MOZART are used as spatially and temporally varying chemical boundary conditions. In the second ("Mean BC") the chemical boundary conditions are taken from the MOZART fields averaged over the time period of 

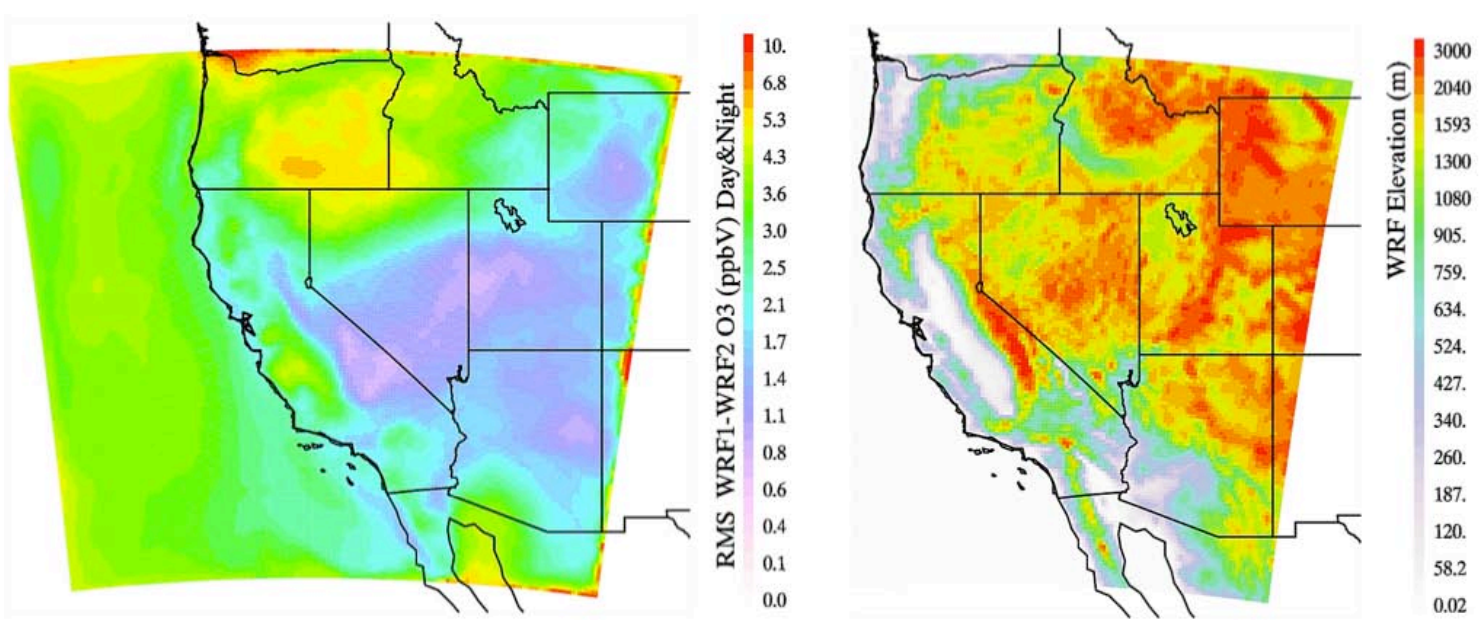

Fig. 11. Left hand side: RMS difference in surface $\mathrm{O}_{3}$ between the WRF-Chem simulations with temporally varying and with temporally averaged chemical boundary conditions. Right hand side: Elevation $(\mathrm{m})$ over the regional domain.

the WRF-Chem simulation (14-30 June 2008). Both simulations start from the same initial conditions and model fields are output every two hours. The mean and standard deviation of the $\mathrm{CO}$ and $\mathrm{O}_{3}$ chemical inflow for "Variable BC" (this is represented by $\mathrm{AVG}^{\text {RegionTime }}$ for Ocean without fire filtering) is $104 \pm 14 \mathrm{ppbV}$ and $50 \pm 12 \mathrm{ppbV}$, respectively. The $10-90$ th range spanned by the model results is $27 \mathrm{ppbV}$ for $\mathrm{CO}$ and $28 \mathrm{ppbV}$ for $\mathrm{O}_{3}$. In comparison, for the "Mean BC" scenario $\mathrm{CO}$ and $\mathrm{O}_{3}$ mean concentrations (applying the same averaging as for $\mathrm{AVG}^{\text {RegionTime }}$ to the mean modeled fields) are $104 \pm 4 \mathrm{ppbV}$ and $50 \pm 4 \mathrm{ppbV}$ with $10-90 \%$ ranges of $11 \mathrm{ppbV}$ and $11 \mathrm{ppbV}$, respectively (Table 2). In other words, the variability and range in the inflow is reduced by a factor of nearly 3 for the mean $\mathrm{BC}$ simulation compared to the variable BC simulation. While beyond the scope of this study, we present in the Supplement, analogous to Figs. 2, 3 and 5, a comparison of MOZART and WRF-Chem results to the aircraft data.

In Fig. 10 we present maps of daily average difference in surface $\mathrm{O}_{3}$ between the "Variable BC" and the "Mean BC" simulation. During the first days of the simulations differences are mostly seen around the outer edges of the domain, but after three days we see clear changes in the surface concentrations throughout the domain aproaching about \pm 15 ppbV over California with a large spatial and temporal variability. Figure 11 shows the root mean square (RMS) difference for the entire simulation period together with a map of the domain topography. High altitude locations commonly are expected to show the largest sensitivity to pollution inflow and are considered as most representative for pollution inflow. However, our results show the largest RMS differences (up to $5 \mathrm{ppbV}$ ) not necessarily at the high altitudes, but in the Central Valley region, which is a lower altitude area. A similar pattern is also seen for the RMS differences in surface $\mathrm{CO}$ (not shown here). Varying concentrations of $\mathrm{O}_{3}$ in onshore flow have recently been shown to have a strong influence on measured surface $\mathrm{O}_{3}$ concentrations in the Central Valley. Parrish et al. (2010) found that measured surface $\mathrm{O}_{3}$ concentrations correlate with the $\mathrm{O}_{3}$ measured in the lower free troposphere by the Trinidad Head sondes after allowing for a time delay of approximately $20 \mathrm{~h}$. On days that surface $\mathrm{O}_{3}$ exceeded the air quality standard of $75 \mathrm{ppbv}$, the transported $\mathrm{O}_{3}$ as measured by the sondes averaged $11 \mathrm{ppbv}$ higher compared to days with lower $\mathrm{O}_{3}$ observed at the surface.

Histograms of the percentage differences between "Variable BC" and "Mean BC" simulations for surface concentrations for $\mathrm{O}_{3}, \mathrm{CO}, \mathrm{NO}_{\mathrm{x}}$ and PAN over California are shown in Fig. 12. $\mathrm{CO}$ and $\mathrm{NO}_{\mathrm{x}}$, which are strongly source driven and as such highest near local emission sources, show smaller relative changes compared to the more photochemically driven species $\mathrm{O}_{3}$ and PAN, which are formed photochemically during transport. The frequency of cases where changes amount to $\pm 10 \%$ or more are $9 \%$ for $\mathrm{O}_{3}, 11.5 \%$ for PAN, and $\sim 1 \%$ for $\mathrm{CO}$ and $\mathrm{NO}_{\mathrm{x}}$.

Statistics show that in the "Mean BC" simulation, where incoming plumes are smoothed due to the averaging, the number of extreme values is reduced for all species. The concentration distributions are more strongly peaked in the medium value range with less pronounced high and low concentration tails (not shown here), with the high end of the distribution being of special relevance for air quality issues. To address this issue we examine how the temporal variability of BC impacts the frequency of exceedances of the 8-h averaging $\mathrm{O}_{3}$ standard (currently set at $75 \mathrm{ppbV}$ with a possible reduction to within the 60 to $70 \mathrm{ppbV}$ range). Considering changes over the whole of California (including all urban areas), the average overall effect is modest with the frequency of exceedances of the standards changing by less than about $1 \%$ between the two model simulations. Considering 


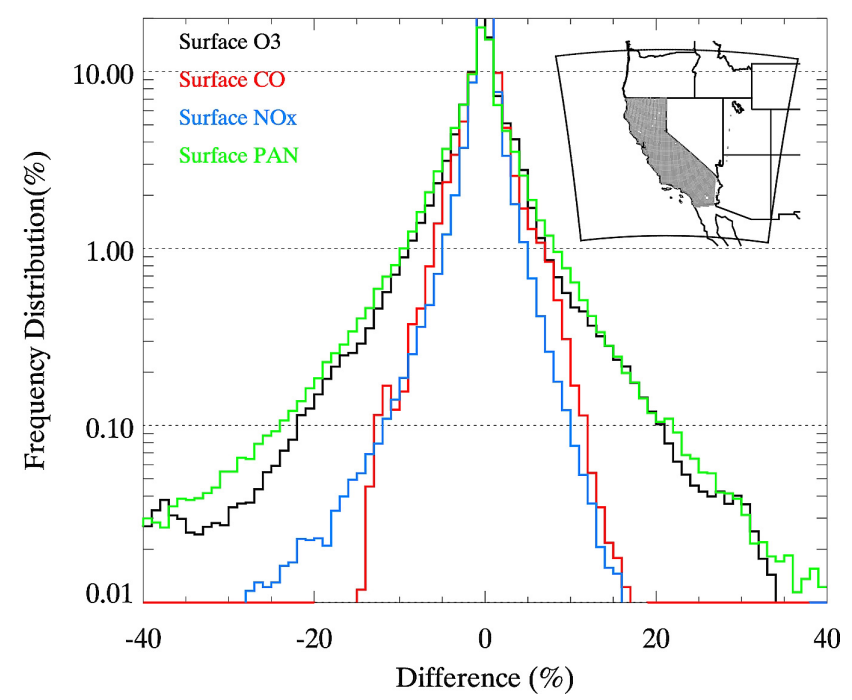

Fig. 12. Histograms in the percentage difference between surface concentrations of $\mathrm{O}_{3}, \mathrm{CO}, \mathrm{NO}_{\mathrm{x}}$ and PAN over California between the WRF-Chem simulations with temporally varying and with temporally averaged chemical boundary conditions.

only California surface data where the $\mathrm{BC}$ have a distinct influence (absolute difference in surface $\mathrm{O}_{3}$ between "Variable BC" and "Mean BC" >3 ppbV, which includes $12 \%$ of all surface data over California), the daily 8-h maximum $\mathrm{O}_{3}$ concentrations exceeded $75 \mathrm{ppbV}(65 \mathrm{ppbV})$ in the "Variable BC" simulation on $10 \%(25 \%)$ of the days modeled. In the "Mean BC" simulation, these frequencies were reduced to $8 \%(18 \%)$. It must be considered that these statistics may not quite represent a typical influence of pollution inflow. The considered time period was significantly impacted by the intense wildfires, which may have in parts mitigated the influence of pollution inflow. However, the estimated sensitivities might even be on the lower end during strong long-range pollution events, which, as was discussed in Sect. 3.1, are strongly underestimated in a global model.

\section{Conclusions}

We have presented an analysis of measurements of the longlived tracers $\mathrm{CO}, \mathrm{O}_{3}$ and PAN combined with global model simulations to examine the characteristics of airmasses entering the US West Coast. The data sets were collected on four platforms: the NASA-DC8 aircraft during ARCTAS-CARB in June 2008 (with all three species measured), the TES satellite $\left(\mathrm{CO}\right.$ and $\left.\mathrm{O}_{3}\right)$, MOZAIC aircraft $\left(\mathrm{CO}\right.$ and $\left.\mathrm{O}_{3}\right)$ and $\mathrm{O}_{3}$ sondes launched from Trinidad Head, California. Both observations and models reflect a large variability in pollution inflow on temporal and spatial scales, but the MOZART global model captured only about half of the observed free tropospheric variability. Sensitivity studies with a regional model demonstrate that the representation of the variability in pol- lution inflow (i.e. the lateral boundary conditions of regional models) has significant influence on surface air quality over California. As a result, we suggest that boundary conditions from global models provide useful input to regional models, but likely still lead to an underestimate of peak surface concentrations associated with long-range pollution transport. It therefore is important to carefully evaluate the chemical boundary conditions implemented in regional air quality simulations not only for their representation of the overall background, but also for their representativeness of spatial and temporal variability and frequency distributions.

Model tracer contributions show a large contribution from Asian emissions on FT air masses. Local US pollution can impact chemical boundary conditions both by recirculation within the eastern Pacific region, and by around-the-world transport in the case of long-lived tracers. This emphasizes the importance of consistency between the global model simulations used for boundary conditions and the regional model in terms of emissions, chemistry and transport. To mitigate the influence of the boundary conditions, nested regional domains with a sufficiently large outer domain are an option but not always possible as they involve a large computational demand.

Aircraft measurements in the free troposphere over California show similar concentration range, variability and source contributions as free tropospheric air masses over ocean, but caution has to be taken that lofted local pollution is not misinterpreted as inflow. In the case of the June 2008 period the intense wildfire pollution was seen to have a significant impact on the free troposphere over land. The especially designed boundary conditions flight conducted during ARCTAS-CARB showed an above average prevalence of plumes transported from Asia and thus may not be fully representative for average inflow conditions.

Owing to the large variability in atmospheric transport, more frequent free tropospheric measurements are needed to better characterize pollution inflow and to evaluate and improve (e.g. through model improvements and/or data assimilation) chemical boundary conditions used in regional model simulations. The evaluation of boundary conditions must be a crucial part of regional model evaluation, especially for regions like California where pollution inflow embodies a significant contribution to air quality.

\section{Supplementary material related to this article is available online at: http://www.atmos-chem-phys.net/11/1769/2011/ acp-11-1769-2011-supplement.pdf.}

Acknowledgements. The authors like to acknowledge Ajith Kaduwela and Jeremy Avise (CARB) for providing emission estimates for California and Stu McKeen (NOAA ESRL) for support in using the EPA-NEI emissions inventory. We further acknowledge Jean-Francois Lamarque and Anne Boynard for providing valuable input to the manuscript. The authors further like 
to thank the reviewers for their constructive comments and suggestions. Acetonitrile measurements were supported by the Austrian Research Promotion Agency (FFG-ALR) and the Tiroler Zukunftstiftung and carried out with the help/support of T. Mikoviny, M. Graus, A. Hansel and T. D. Maerk. The authors acknowledge the strong support of the European Commission, Airbus, and the Airlines (Lufthansa, Austrian, Air France) who carry free of charge the MOZAIC equipment and perform the maintenance since 1994. MOZAIC is presently funded by INSU-CNRS (France), Meteo-France, and Forschungszentrum (FZJ, Julich, Germany). The MOZAIC data based is supported by ETHER (CNES and INSU-CNRS). The research was supported by NASA grants NNX10AH45G, NNX08AD22G and NNX07AL57G. NCAR is operated by the University Corporation of Atmospheric Research under sponsorship of the National Science Foundation.

Edited by: A. Stohl

\section{References}

Beer, R.: TES on the Aura mission: Scientific objectives, measurements, and analysis overview, IEEE Trans. Geosci. Remote Sens., 44 (5), 1102-1105, 2006.

Bertschi, I. T., Jaffe, D. A., Jaeglé, L., Price, H. U., and Dennison, J. B.: PHOBEA/ITCT 200225 airborne observations of transpacific transport of ozone, $\mathrm{CO}$, volatile organic compounds, and aerosols to the northeast Pacific: Impacts of Asian anthropogenic and Siberian boreal fire emissions, J. Geophys. Res., 109, D23S12, doi:10.1029/2003JD004328, 2004.

Brown, J. A., Jr.: Operational numerical weather prediction, Rev. Geophys., 25(3), 312-322, doi:10.1029/RG025i003p00312, 1987.

Chin, M., Ginoux, P., Kinne, S. Holben, B. N., Duncan, B. N, Martin, R. V., Logan, J. A, Higurashi, J., and Nakajima, T.: Tropospheric aerosol optical thickness from the GOCART model and comparisons with satellite and sunphotometer measurements, J. Atmos. Sci. 59, 461-483, 2002.

Diskin, G. S., Podolske, J. R., Sachse, G. W., and Slate, T. A.: Open-Path Airborne Tunable 15 Diode Laser Hygrometer, in Diode Lasers and Applications in Atmospheric Sensing, SPIE Proceedings 4817, A. Fried, ed., 196-204, 2002.

Ek, M. B., Mitchell, K. E. Lin, Y., Rogers, E., Grunmann, P., Koren, V., Gayno, G., and Tarpley, J. D.: Implementation of Noah land surface model advances in the National Centers for Environmental Prediction operational mesoscale Eta model, J. Geophys. Res., 108(D22), 8851, doi:10.1029/2002JD003296, 2003.

Emmons, L. K., Walters, S., Hess, P. G., Lamarque, J.-F., Pfister, G. G., Fillmore, D., Granier, C., Guenther, A., Kinnison, D., Laepple, T., Orlando, J., Tie, X., Tyndall, G., Wiedinmyer, C., Baughcum, S. L., and Kloster, S.: Description and evaluation of the Model for Ozone and Related chemical Tracers, version 4 (MOZART-4), Geosci. Model Dev., 3, 43-67, doi:10.5194/gmd3-43-2010, 2010a.

Emmons, L. K., Apel, E. C., Lamarque, J.-F., Hess, P. G., Avery, M., Blake, D., Brune, W., Campos, T., Crawford, J., DeCarlo, P. F., Hall, S., Heikes, B., Holloway, J., Jimenez, J. L., Knapp, D. J., Kok, G., Mena-Carrasco, M., Olson, J., O’Sullivan, D., Sachse, G., Walega, J., Weibring, P., Weinheimer, A., and Wiedinmyer, C.: Impact of Mexico City emissions on regional air quality from
MOZART-4 simulations, Atmos. Chem. Phys., 10, 6195-6212, doi:10.5194/acp-10-6195-2010, 2010b.

Fast, J., Aiken, A. C., Allan, J., Alexander, L., Campos, T., Canagaratna, M. R., Chapman, E., DeCarlo, P. F., de Foy, B., Gaffney, J., de Gouw, J., Doran, J. C., Emmons, L., Hodzic, A., Herndon, S. C., Huey, G., Jayne, J. T., Jimenez, J. L., Kleinman, L., Kuster, W., Marley, N., Russell, L., Ochoa, C., Onasch, T. B., Pekour, M., Song, C., Ulbrich, I. M., Warneke, C., WelshBon, D., Wiedinmyer, C., Worsnop, D. R., Yu, X.-Y., and Zaveri, R.: Evaluating simulated primary anthropogenic and biomass burning organic aerosols during MILAGRO: implications for assessing treatments of secondary organic aerosols, Atmos. Chem. Phys., 9, 6191-6215, doi:10.5194/acp-9-6191-2009, 2009.

Fiore, A. M., Dentener, F. J., Wild, O., Cuvelier, C., Schultz, M. G., Hess, P., Textor, C., Schulz, M., Doherty, R. M., Horowitz, L. W., MacKenzie, I. A., Sanderson, M. G., Shindell, D. T., Stevenson, D. S., Szopa, S., Van Dingenen, R., Zeng, G., Atherton, C., Bergmann, D., Bey, I., Carmichael, G., Collins, W. J., Duncan, B. N., Faluvegi, G., Folberth, G., Gauss, M., Gong, S., Hauglustaine, D., Holloway, T., Isaksen, I. S. A., Jacob, D. J., Jonson, J. E., Kaminski, J. W., Keating, T. J., Lupu, A., Marmer, E., Montanaro, V., Park, R. J., Pitari, G., Pringle, K. J., Pyle, J. A., Schroeder, S., Vivanco, M. G., Wind, P., Wojcik, G., Wu, S., and Zuber, A.: Multimodel estimates of intercontinental sourcereceptor relationships for ozone pollution, J. Geophys. Res., 114, D04301, doi:10.1029/2008JD010816, 2009.

Freitas, S. R., Longo, K. M., Chatfield, R., Latham, D., Silva Dias, M. A. F., Andreae, M. O., Prins, E., Santos, J. C., Gielow, R., and Carvalho Jr., J. A.: Including the sub-grid scale plume rise of vegetation fires in low resolution atmospheric transport models, Atmos. Chem. Phys., 7, 3385-3398, doi:10.5194/acp-7-33852007, 2007.

Granier, C., Mueller, J. F., Petron, G. and Brasseur, G.: A threedimensional study of the CO budget, Glob. Change Science, 1, 255-261, 1999.

Grell, G. A., Peckham, S. E., Schmitz, R., McKeen, S. A., Frost, G., Skamarock, W. C., and Eder, B.: Fully coupled online chemistry within the WRF model, Atmos. Environ., 39, 6957-6975, 2005.

Guenther, A., Karl, T., Harley, P., Wiedinmyer, C., Palmer, P. I., and Geron, C.: Estimates of global terrestrial isoprene emissions using MEGAN (Model of Emissions of Gases and Aerosols from Nature), Atmos. Chem. Phys., 6, 3181-3210, doi:10.5194/acp-63181-2006, 2006.

Heald, C. L., Jacob, J., Fiore, A. M., Emmons, L. K., Gille, J. C., Deeter, M. N., Warner, J., Edwards, D. P., Crawford, J. H., Hamlin, A. J., Sachse, G. W., Browell, E. V., Avery, M. A., Vay, S. A., Westberg, D. J., Blake, D. R., Singh, H. B., Sandholm, S. T., Talbot, R. W., and Fuelberg, H. E.: Asian outflow and transPacific transport of carbon monoxide and ozone pollution: An integrated satellite, aircraft, and model perspective, J. Geophys. Res., 108(D24), 17, 4804, doi:10.1029/2003JD003507, 2003.

Hess, P. G. and Lamarque, J. F.: Ozone source attribution and its modulation by the Arctic oscillation during the spring months, J. Geophys. Res., 112, D11303, doi:10.1029/2006JD007557, 2007.

Horowitz, L., Walters, S., and Mauzerall, D.S.: A global simulation of tropospheric ozone and related tracers: Description and evaluation of MOZART, version 2, J. Geophys. Res., 108, 4784, 25 pp., doi:10.1029/2002JD002853, 2003.

Huang, M., Carmichael, G. R., Adhikary, B., Spak, S. N., Kulkarni, 
S., Cheng, Y. F., Wei, C., Tang, Y., Parrish, D. D., Oltmans, S. J., D’Allura, A., Kaduwela, A., Cai, C., Weinheimer, A. J., Wong, M., Pierce, R. B., Al-Saadi, J. A., Streets, D. G., and Zhang, Q.: Impacts of transported background ozone on California air quality during the ARCTAS-CARB period - a multi-scale modeling study, Atmos. Chem. Phys., 10, 6947-6968, doi:10.5194/acp-106947-2010, 2010.

Jacob, D. J., Crawford, J. H., Maring, H., Clarke, A. D., Dibb, J. E., Emmons, L. K., Ferrare, R. A., Hostetler, C. A., Russell, P. B., Singh, H. B., Thompson, A. M., Shaw, G. E., McCauley, E., Pederson, J. R., and Fisher, J. A.: The Arctic Research of the Composition of the Troposphere from Aircraft and Satellites (ARCTAS) mission: design, execution, and first results, Atmos. Chem. Phys., 10, 5191-5212, doi:10.5194/acp-10-5191-2010, 2010.

Jacob, D. J., Logan, J. A., and Murti, P. P.: Effect of rising Asian emissions on surface ozone in the United States, Geophys. Res. Lett., 26(14), 2175-2178, 1999.

Janjic, Z. I.: Nonsingular Implementation of the Mellor-Yamada Level 2.5 Scheme in the NCEP Meso model. NCEP Office Note No. 437, 61 pp., 2002.

Johnson, B. J., Oltmans, S. J., Voemel, H., Smit, H. G. J., Deshler, T., and Kröger, C.: Electrochemical concentration cell (ECC) ozonesonde pump efficiency measurements and tests on the sensitivity to ozone of buffered and unbuffered ECC sensor cathode solutions, J. Geophys. Res., 107(D19), 4393, doi:10.1029/2001JD000557, 2002.

Jourdain, L., Worden, H. M., Worden, J. R., Bowman, K., Li, Q., Eldering, A., Kulawik, S. S., Osterman, G., Boersma, K. F., Fisher, B., Rinsland, C. P., Beer, R., and Gunson, M.: Tropospheric vertical distribution of tropical Atlantic ozone observed by TES during the Northern African biomass burning season, Geophys. Res. Lett., 34, L04810, doi:10.1029/2006GL028284, 2007.

Lamarque, J.-F., Hess, P., Emmons, L., Buja, L., Washington, W., and Granier, C.: Tropospheric ozone evolution between 1890 and 1990, J. Geophys. Res., 110, D08304, doi:10.1029/2004JD005537, 2005.

Li, Q., Jacob, D. J., Palmer, P. I, Duncan, B. N., Field, B. D., Fiore, A. M., Yantosca, R. M., Parrish, D. D., Simmonds, P. G., and Oltsman S.: Transatlantic transport of pollution and its effects on surface ozone in Europe and North America, J. Geophys. Res., 107, doi:10.1029/2001JD001422, 2002.

Li, Q., Jacob, D. J. Munger, J. W., Yantosca, R. M, and Parrish, D. D.: Export of NOy from the North American boundary layer: Reconciling aircraft observations and global model budgets, J. Geophys. Res., 109, D02313, doi:10.1029/2003JD004086, 2004.

Lin, M., Holloway, T., Carmichael, G. R., and Fiore, A. M.: Quantifying pollution inflow and outflow over East Asia in spring with regional and global models, Atmos. Chem. Phys., 10, 42214239, doi:10.5194/acp-10-4221-2010, 2010.

Lopez, J. P., Luo, M., Christensen, L. E., Loewenstein, M., Jost, H., Webster, C. R., and Osterman, G.: TES carbon monoxide validation during two AVE campaigns using the Argus and ALIAS instruments on NASA's WB-57F, J. Geophys. Res., 113, D16S47, doi:10.1029/2007JD008811, 2008.

Luo, M., Rinsland, C., Fisher, B., Sachse, G., Diskin, G., Logan, J., Worden, H., Kulawik, S., Osterman, G., Eldering, A., Herman, R., and Shephard, M.: TES carbon monoxide validation with DACOM aircraft measurements during INTEX-B 2006, J. Geophys. Res., 112, D24S48, doi:10.1029/2007JD008803, 2007.
Marenco, A., Thouret, V. Nedelec, P., Smit, H., Helten, M., Kley, D., Karcher, F., Simon, P., Law, K., Pyle, J., Poschmann, G., von Wrede, R., Hume, C., and Cook, T.: Measurement of ozone and water vapour by Airbus in-service aircraft: The MOZAIC airborne program, an overview, J. Geophys. Res., 103, 2563125642, 1998.

Mena-Carrasco, M., Carmichael, G. R., Campbell, J. E., Zimmerman, D., Tang, Y., Adhikary, B., Dallura, A., Molina, L. T., Zavala, M., Garca, A., Flocke, F., Campos, T., Weinheimer, A. J., Shetter, R., Apel, E., Montzka, D. D., Knapp, D. J., and Zheng, W.: Assessing the regional impacts of Mexico City emissions on air quality and chemistry, Atmos. Chem. Phys., 9, 3731-3743, doi:10.5194/acp-9-3731-2009, 2009.

Nassar, R., Logan, J. A., Worden, H., Megretskaia, I. A., Bowman, K. W., Osterman, G. B., Thompson, A. M., Tarasik, D. W., Austin, S., Claude, H.,Dubey, M. K.,Hocking, W. K., Johnson, B. J., Joseph, E., Merrill, J., Morris, G. A., Newchurch, M., Oltmans, S. J., Posny, F., Schmidlin, F. J., Voemel, H., Whiteman, D. N., and Witte, J. C.: Validation of Tropospheric Emission Spectrometer (TES) nadir ozone profiles using ozonesonde measurements, J. Geophys. Res., 113, D15S17, doi:10.1029/2007JD008819, 2008.

Nedelec, P., Cammas, J.-P., Thouret, V., Athier, G., Cousin, J.-M., Legrand, C., Abonnel, C., Lecoeur, F., Cayez, G., and Marizy, C.: An improved infrared carbon monoxide analyser for routine measurements aboard commercial Airbus aircraft: technical validation and first scientific results of the MOZAIC III programme, Atmos. Chem. Phys., 3, 1551-1564, doi:10.5194/acp-3-15512003, 2003.

Oltmans, S. J., Lefohn, A. S., Harris, J. M., and Shadwick, D. S.: Background ozone levels of air entering the west coast of the US and assessment of longer-term changes, Atmos. Environ., 42, 6020-6038, 2008.

Osterman, G., Kulawik, S., Worden, H., Richards, N., Fisher, B., Eldering, A., Shephard, M., Froidevaux, L., Labow, G., Luo, M., Herman, R., and Bowman, K.: Validation of Tropospheric Emission Spectrometer (TES) Measurements of the Total, Stratospheric and Tropospheric Column Abundance of Ozone, J. Geophys. Res., 113, D15S16, doi:10.1029/2007JD008801, 2008.

Osterman, G. (Ed.), Bowman, K., Eldering, A., Fisher, B., Herman, R., Jacob, D., Jourdain, L., Kuawik, S., Luo, M., Monarrez, R., Paradise, S., Payne, V., Poosti, S., Richards, N., Rider, D., 5 Shephard, D., Shephard, M., Vilntotter, F., Worden, H., Worden, J., Yun, H., and Zhang, L.: TES Level 2 Data Users Guide, v4.0, JPL D-38042, 20 May 2009, available at: http://tes.jpl.nasa.gov/ documents/, 2009.

Parrish, D. D., Holloway, J. S., Trainer, M., Murphy, P. C., Fehsenfeld, F. C., and Forbes, G. L.: Export of North America ozone pollution to the North Atlantic Ocean, Science, 259(5100), 1436-1439, 1993.

Parrish, D. D., Aikin, K. C., Oltmans, S. J., Johnson, B. J., Ives, M., and Sweeny, C.: Impact of transported background ozone inflow on summertime air quality in a California ozone exceedance area, Atmos. Chem. Phys., 10, 10093-10109, doi:10.5194/acp10-10093-2010, 2010.

Pfister, G., Petron, G., Emmons, L. K., Gille, J. C., Edwards, D. P., Lamarque, J.-F., Attie, J.-L., Granier, C., and Novelli, P. C.: Evaluation of CO simulations and the analysis of the CO budget for Europe, J. Geophys. Res., 109, D19304, 
doi:10.1029/2004JD004691, 2004.

Pfister, G. G., Emmons, L. K., Hess, P. G., Honrath, R., Lamarque, J. F., val Martin, M., Owen, R. C., Avery, M. A., Browell, E. V., Holloway, J. S., Nedelec, P., Purvis, R., Ryseron, T. B., Sachse, G. W., and Schlager, H.: Ozone production from the 2004 North American boreal fires, J. Geophys. Res., 111, D24S07, doi:10.1029/2006JD007695, 2006.

Pfister, G. G., Emmons, L. K., Hess, P. G., Lamarque, J.-F., Orlando, J. J., Walters, S., Guenther, A., Palmer, P. I., and Lawrence, P. J.: Contribution of isoprene to chemical budgets: A model tracer study with the NCAR CTM MOZART-4, J. Geophys. Res., 113, D05308, doi:10.1029/2007JD008948, 2008a.

Pfister, G. G., Emmons, L. K., Hess, P. G., Lamarque, J.-F., Thompson, A. M., and Yorks, J. E.: Analysis of the Summer 2004 ozone budget over the United States using Intercontinental Transport Experiment Ozonesonde Network Study (IONS) observations and Model of Ozone and Related Tracers (MOZART-4) simulations, J. Geophys. Res., 113, D23306, doi:10.1029/2008JD010190, 2008b.

Pfister, G. G., Emmons, L. K., Edwards, D. P., Arellano, A., G Sachse, and Campos, T.: Variability of springtime transpacific pollution transport during 20002006: the INTEX-B mission in the context of previous years, Atmos. Chem. Phys., 10, 13451359, doi:10.5194/acp-10-1345-2010, 2010.

Rastigejev, Y., Park, R., Brenner, M. P., and Jacob, D. J.: Resolving intercontinental pollution plumes in global models of atmospheric transport, J. Geophys. Res., 115, D02302, doi:10.1029/2009JD012568, 2010.

Richards, N. A. D., Osterman, G. B., Browell, E. V., Hair, J. W., Avery, M., and Li, Q. : Validation of Tropospheric Emission Spectrometer ozone profiles with aircraft observations during the Intercontinental Chemical Transport Experiment B, J. Geophys. Res., 113, D16S29, doi:10.1029/2007JD008815, 2008.

Rinsland, C. P., Luo, M. , Logan, J. A., Beer, R., Worden, H., Kulawik, S. S., Rider, D., 10 Osterman, G., Gunson, M., Eldering, A., Goldman, A., Shephard, M., Clough, S. A., Rodgers, C., Lampel, M., and Chiou, L.: Nadir Measurements of carbon monoxide distributions by the Tropospheric Emission Spectrometer onboard the Aura Spacecraft: Overview of analysis approach and examples of initial results, Geophys. Res. Lett., 33, L22806, doi:10.1029/2006GL027000, 2006.

Sachse, G. W., Hill, G. F., Wade, L. O., and Perry, M. G.: Fastresponse, high-precision carbon monoxide sensor using a tunable diode laser absorption technique, J. Geophys. Res., 92, 20712081, 1987.

Slusher, D. L., Huey, L. G., Tanner, D. J., Flocke, F. M., and Roberts, J. M.: A thermal dissociation-chemical ionization mass spectrometry (TD-CIMS) technique for the simultaneous measurement of peroxyacyl nitrates and dinitrogen pentoxide, J. Geophys. Res., 109, D19315, doi:10.1029/2004JD004670, 2004.

Stohl, A., Eckhardt, S., Forster, C., James, P., and Spichtinger, N.: On the pathways and timescales of intercontinental air pollution transport, J. Geophys. Res.-Atmos., 107(D23), 4684, doi:10.1029/2001JD001396, 2002.

Tang, Y. H., Carmichael, G. R., Thongboonchoo, N., Chai, T. F., Horowitz, L. W., Pierce, R., Al-Saadi, J. A., Pfister, G., Vukovich, J. M., Avery, M. A., Sachse, G. W., Ryerson, T. B., 30 Holloway, J. S., Atlas, E. L., Flocke, F. M., Weber, R. J., Huey, L. G., Dibb, J. E., Streets, D., and Brune, W. H.: Influ- ence of lateral and top boundary conditions on regional air quality prediction: A multiscale study coupling regional and global chemical transport models, J. Geophys. Res., 112, D10S18, doi:10.1029/2006JD007515, 2007.

Thouret, V., Marenco, A., Logan, J. A., Nédélec, P., and Grouhel, C.: Comparisons of ozone measurements from the MOZAIC airborne program and the ozone sounding network at eight locations, J. Geophys. Res., 103(D19), 25695-25720, doi:10.1029/98JD02243, 1998.

Val Martín, M., Honrath, R. E., Owen, R. C., Pfister, G., Fialho, P., and Barata, F.: Significant enhancements of nitrogen oxides, black carbon, and ozone in the North Atlantic lower free troposphere resulting from North American boreal wildfires, J. Geophys. Res., 111, D23S60, doi:10.1029/2006JD007530, 2006.

Warner, T. T., Peterson, R. A., and Treadon, R. E.: A tutorial on lateral boundary conditions as a basic and potentially serious limitation to regional numerical weather prediction, B. Am. Meteorol. Soc., 78, 2599-2617, 1997.

Weinheimer, A. J., Walega, J. G., Ridley, B. A., Gary, B. L., Blake, D. R., Blake, N. J., Rowland, F. S., Sachse, G. W., Anderson, B. E., and Collins, J. E.: Meridional distributions of $\mathrm{NO}_{\mathrm{x}}, \mathrm{NO}_{\mathrm{y}}$, and other species in the lower stratosphere and upper troposphere during AASE II, Geophys. Res. Lett., 21, 2583-2586, 1994.

Wiedinmyer, C., Quayle, B ., Geron, C., Belote, A., McKenzie, D., Zhang, X., O’Neill, S. and Wynne, K. K.: Estimating emissions from fires in North America for air quality monitoring, Atmos. Environ., 40, 3419-3432, 2006.

Wiedinmyer, C., Akagi, S. K., Yokelson, R. J., Emmons, L. K., AlSaadi, J. A., Orlando, J. J., and Soja, A. J.: The Fire INventory from NCAR (FINN) a high resolution global model to estimate the emissions from open burning, Geosci. Model Dev. Discuss., 3, 2439-2476, doi:10.5194/gmdd-3-2439-2010, 2010.

Worden, H. M., Logan, J. A., Worden, J. R., Beer, R., Bowman, K., Clough, S. A., Eldering, A., Fisher, B. M., Gunson, M. R., Herman, R. L., Kulawik, S. S., Lampel, M. C., Luo, M., Megretskaia, I. A., Osterman, G. B., and Shephard, M. W.: Comparisons of Tropospheric Emission Spectrometer (TES) ozone profiles to ozonesondes: Methods and initial results, J. Geophys. Res., 112, D03309, doi:10.1029/2006JD007258, 2007.

Zhang, L., Jacob, D. J., Boersma, K. F., Jaffe, D. A., Olson, J. R., Bowman, K. W., Worden, J. R., Thompson, A. M., Avery, M. A., Cohen, R. C., Dibb, J. E., Flock, F. M., Fuelberg, H. E., Huey, L. G., McMillan, W. W., Singh, H. B., and Weinheimer, A. J.: Transpacific transport of ozone pollution and the effect of recent Asian emission increases on air quality in North America: an integrated analysis using satellite, aircraft, ozonesonde, and surface observations, Atmos. Chem. Phys., 8, 6117-6136, doi:10.5194/acp-8-6117-2008, 2008.

Ziemke, J. R., Chandra, S., Duncan, B. N., Froidevaux, L., Bhartia, P. K., Levelt, P. F., and Waters, J. W.: Tropospheric ozone determined from Aura OMI and MLS: Evaluation of measurements and comparison with the Global Modeling Initiatives Chemical Transport Model, J. Geophys. Res., 111, D19303, doi:10.1029/2006JD007089, 2006. 